\title{
Recognition and Management of Antipsychotic-Induced Parkinsonism in Older Adults: A Narrative Review
}

\author{
Sharadha Wisidagama ${ }^{1}$, Abiram Selladurai ${ }^{1}$, Peter Wu ${ }^{1}$, Marco Isetta ${ }^{2}$ and Jordi Serra-Mestres ${ }^{3, *(D)}$ \\ 1 Departments of Psychiatry, Central and North West London NHS Foundation Trust, London NW1 3AX, UK; \\ sharadha.wisidagama@nhs.net (S.W.); aselladurai@nhs.net (A.S.); peter.wu@nhs.net (P.W.) \\ 2 Knowledge and Library Services, Central and North West London NHS Foundation Trust, \\ London NW1 3AX, UK; marco.isetta@nhs.net \\ 3 Old Age Psychiatry, Central and North West London NHS Foundation Trust, Uxbridge UB8 3NN, UK \\ * Correspondence: jordi.serra-mestres@nhs.net; Tel.: +44-0-1895-484911
}

Citation: Wisidagama, S.; Selladurai, A.; Wu, P.; Isetta, M.; Serra-Mestres, J. Recognition and Management of Antipsychotic-Induced Parkinsonism in Older Adults: A Narrative Review. Medicines 2021, 8, 24. https:// doi.org/10.3390/medicines8060024

Academic Editor: Maurits Van den Noort

Received: 7 April 2021

Accepted: 23 May 2021

Published: 26 May 2021

Publisher's Note: MDPI stays neutral with regard to jurisdictional claims in published maps and institutional affiliations.

Copyright: (c) 2021 by the authors. Licensee MDPI, Basel, Switzerland. This article is an open access article distributed under the terms and conditions of the Creative Commons Attribution (CC BY) license (https:/ / creativecommons.org/licenses/by/ $4.0 /)$.
Abstract: Background: Parkinsonism is a common side-effect of antipsychotic drugs especially in older adults, who also present with a higher frequency of neurodegenerative disorders like Idiopathic Parkinson's disease (IPD). Distinguishing between antipsychotic-induced parkinsonism (AIP) and IPD is challenging due to clinical similarities. Up to $20 \%$ of older adults may suffer from persisting parkinsonism months after discontinuation of antipsychotics, suggesting underlying neurodegeneration. A review of the literature on AIP in older adults is presented, focusing on epidemiology, clinical aspects, and management. Methods: A literature search was undertaken on EMBASE, MEDLINE and PsycINFO, for articles on parkinsonism induced by antipsychotic drugs or other dopamine 2 receptor antagonists in subjects aged 65 or older. Results: AIP in older adults is the second most common cause of parkinsonism after IPD. Older age, female gender, exposure to high-potency first generation antipsychotics, and antipsychotic dosage are the main risk factors. The clinical presentation of AIP resembles that of IPD, but is more symmetrical, affects upper limbs more, and tends to have associated motor phenomena such as orofacial dyskinesias and akathisia. Presence of olfactory dysfunction in AIP suggests neurodegeneration. Imaging of striatal dopamine transporters is widely used in IPD diagnosis and could help to distinguish it from AIP. There is little evidence base for recommending pharmacological interventions for AIP, the best options being dosereduction/withdrawal, or switching to a second-generation drug. Conclusions: AIP is a common occurrence in older adults and it is possible to differentiate it from IPD. Further research is needed into its pathophysiology and on its treatment.

Keywords: parkinsonism; antipsychotic drugs; older adults

\section{Introduction}

Extrapyramidal symptoms are well-known side-effects of dopamine 2 receptor (D2R) antagonist drugs, which act on D2Rs in the striatum and mesocortex [1], and comprise a range of acute and tardive motor phenomena, from rigidity, tremor and bradykinesia, to dystonia, dyskinesias, and akathisia. Drug-induced parkinsonism (DIP) refers to a conglomerate of signs that are very similar to, and at times difficult to distinguish from, Idiopathic Parkinson's disease (IPD), and that usually appears and evolves over a period of a few weeks after drug initiation or increase [2]. DIP was first reported following the introduction of antipsychotic drugs (also known as neuroleptics) (APs) as treatment for psychoses in the 1950s, and is more commonly seen with high-potency first generation antipsychotics (FGAs) such as haloperidol [3]. Most cases of DIP are associated with the use of FGAs (especially high-potency ones), and less frequently with second generation antipsychotics (SGAs). However, DIP has also been associated with other families of compounds such as anti-nausea drugs (e.g., substituted benzamides, etc.), calcium channel blockers, sodium valproate, and lithium. Although recovery from DIP after withdrawal 
of the offending drug may take weeks or months, complete recovery is not certain, and around $20 \%$ of patients may continue to experience symptoms thereafter [4]. The risk of developing DIP has been reported to increase with age [5]. In addition, older people are also at a higher risk of emerging neurodegeneration which could compound the differential diagnosis of parkinsonism. In this sense, DIP might sometimes represent the "unmasking" of subclinical nigrostriatal dysfunction secondary to IPD or another $\alpha$-synucleinopathy [6].

A review of the literature was undertaken in order to ascertain the epidemiology of DIP in older adults (aged 65 or older) caused by APs (antipsychotic-induced parkinsonismAIP) as well as D2R antagonists; and establish its clinical characteristics, differential diagnosis, management, and prognosis.

\section{Methods}

A narrative review of the literature reporting on parkinsonism secondary to antipsychotic drugs and other D2R antagonists (such as benzamides) in older adults (aged 65 or older). The search was limited to English articles, or in other languages if English abstracts were available. Editorials, conference papers, letters to the editor and single case reports were excluded.

\section{Database Search Methodology}

Systematic literature searches were performed in the three core healthcare databases: EMBASE and MEDLINE (OVID interface) on 29 December 2020; and PsycINFO (via the NICE HDAS interface) on 30 December 2020. All searches were repeated on 25 February 2021 to capture any recent publications. In order to maximise sensitivity, the search strategies relied on blended subject headings and keyword (free text) approaches-with search language adapted to each database's own syntactical choices.

On MEDLINE, applicable MESH headings (PARKINSON DISEASE, SECONDARY/ and exp ANTIPSYCHOTIC AGENTS/) were supplemented by natural language (neurolepticinduced parkinsonism.ti,ab. or antipsychotic-induced parkinsonism.ti,ab. or drug-induced parkinsonism.ti,ab.). Similarly, the above free-text strings were added to PARKINSONISM/ and (exp NEUROLEPTIC AGENT/ or exp DRUG INDUCED DISEASE/ in EMBASE; and combined with PARKINSONISM/ and exp "SIDE EFFECTS (DRUG)" / in PsycINFO. Age limits (65 years and over) and validated search filters for the aged 65 and older-as reviewed by the InterTASC Information Specialists' Sub-Group (ISSG) were applied across all three searches" (e.g., OVID Medline (aged/ or "aged, 80 and over" / or frail elderly/) OR (elderly or "over 65 " or "over 80 " or "65 year" or " 85 year").ti,ab).

\section{Results with Discussion}

All the retrieved findings (initial searches: EMBASE 662; MEDLINE 337; PsycINFO 218; updated search: 16 for the three databases) were reviewed separately by the authors on agreed inclusion criteria. Individual shortlists were cross-checked and discussed jointly, resulting in a final list of 207 articles for sourcing. 22 selected items could not be obtained as full-text. Additional papers (33) were sourced after revising the selected articles' reference lists. A total of 122 articles were included in the final review. See Figure 1 for a flowchart illustrating search and selection method. 


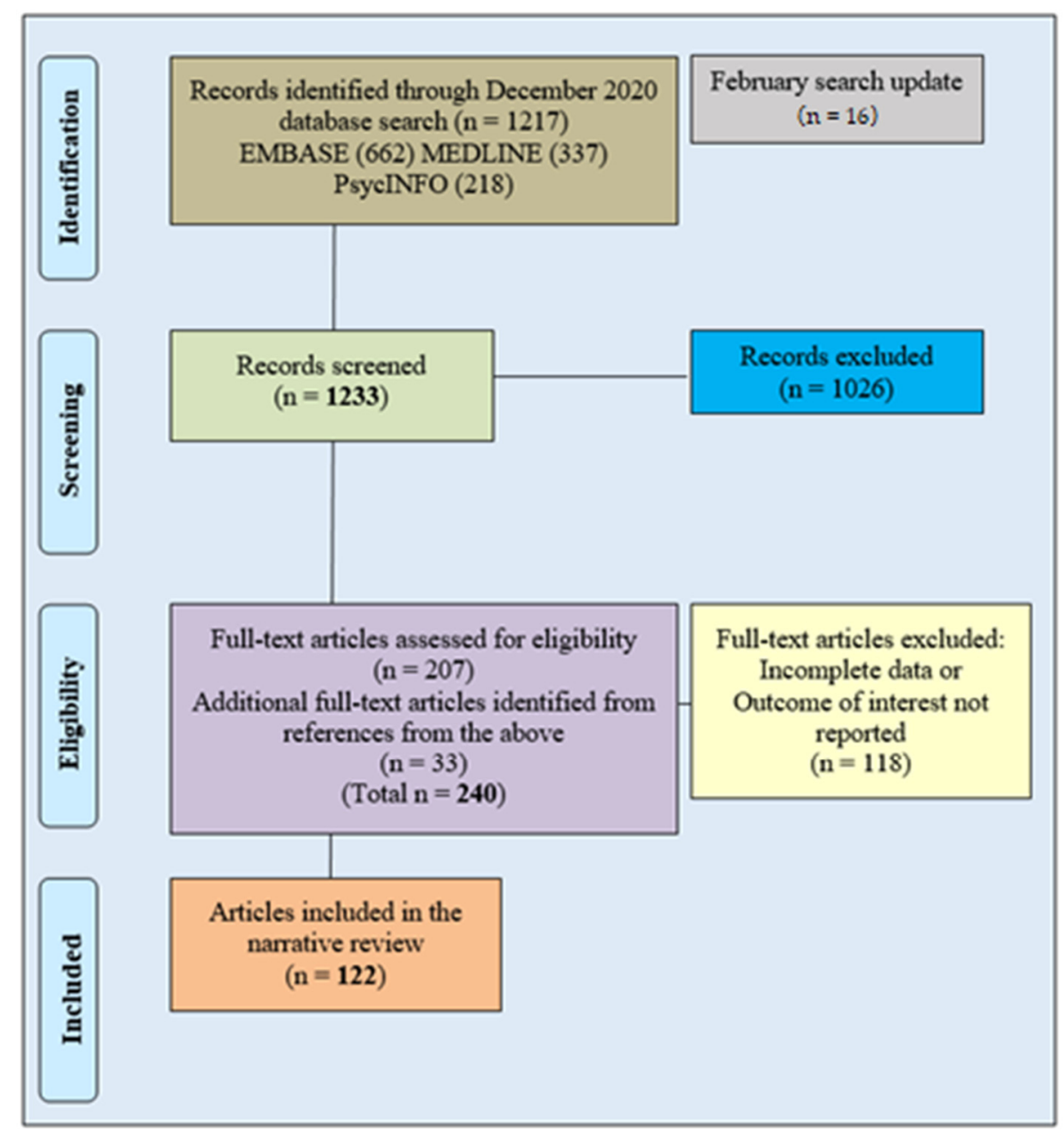

Figure 1. Article search and selection flowchart.

\subsection{Epidemiology and Risk Factors}

Prevalence and incidence rates of DIP vary depending on the ascertainment method and population studied [7], but it has been suggested that globally over $50 \%$ of over 60 years old subjects on long-term therapy with APs develop AIP [8]. For example, among 906 incident cases of parkinsonism in a US community study from 1976 to 2005, 108 persons had DIP (11.9\%) [9]. This study found the incidence of DIP to have increased in older age and in women, but to have decreased overall in that period due to changes in the prescription of APs [9]. Other studies have, however, provided evidence for an overall increase in the annual prevalence of DIP; for example, from 4.09/100,000 in 2009 to 7.02/100,000 in 2015 in a South Korean study [10], which was mainly caused by the use of benzamide derivatives for gastrokinetic indications. See Table 1a,b for the relevant epidemiological studies.

Table 1. Prevalence and Incidence of DIP.

\begin{tabular}{cc}
\hline Study * & Prevalence of DIP \\
\hline $\begin{array}{c}\text { Estevez-Fraga et al., 2018 } \\
\text { Review article }\end{array}$ & $\begin{array}{c}\text { Globally over 50\% of aged 65 } \\
\text { and over }\end{array}$ \\
\hline $\begin{array}{c}\text { Hoffman et al., 1987 } \\
\text { Cross-sectional study in inpatients and outpatients }(n=21)\end{array}$ & $76 \%$ \\
\hline $\begin{array}{c}\text { Morgante et al., 1996 } \\
\text { Prevalence survey in the community population study } \\
(n=24,496)\end{array}$ & $32.7 / 100,000$ \\
\hline
\end{tabular}


Table 1. Cont.

\begin{tabular}{|c|c|}
\hline Study * & Prevalence of DIP \\
\hline $\begin{array}{l}\text { Benito-Leon et al., } 2003 \\
\text { Epidemiological study in the community }(n=5278)\end{array}$ & $0.5 \%$ \\
\hline $\begin{array}{l}\text { Barbosa et al., } 2006 \\
\text { Community based survey }(n=1186)\end{array}$ & $2.7 \%$ \\
\hline $\begin{array}{l}\text { Fleury et al., } 2008 \\
\text { Cross-sectional prevalence study in the community }(n=2312)\end{array}$ & $21.7 / 100,000$ \\
\hline $\begin{array}{c}\text { Buyn et al., } 2019 \\
\text { Korean National Health Insurance Claims Database }(n=1285)\end{array}$ & $\begin{array}{l}4.09 / 100,000 \text { in } 2009 \text { and } \\
7.02 / 100,000 \text { in } 2015\end{array}$ \\
\hline $\begin{array}{c}\text { Han et al., } 2019 \\
\text { Korean National Health Insurance Review and Assessment } \\
\text { Service Database ( } n=\text { circa } 50 \text { million })\end{array}$ & $9.78 / 100,000$ \\
\hline $\begin{array}{l}\text { Khedr et al., } 2015 \\
\text { Cross-sectional community based survey }(n=8027)\end{array}$ & $37 / 100,000$ \\
\hline $\begin{array}{c}\text { Tse et al., } 2008 \\
\text { Cross-sectional study in nursing homes } \\
n=28 / 397 \text { had parkinsonism, } 2 \text { of which had DIP }\end{array}$ & $0.5 \%$ \\
\hline $\begin{array}{l}\text { Moghal et al., } 1995 \\
\text { Survey in nursing homes }(n=67)\end{array}$ & $3 \%$ \\
\hline
\end{tabular}

\begin{tabular}{|c|c|}
\hline Study * & Incidence of DIP \\
\hline $\begin{array}{l}\text { Caligiuri et al., } 1999 \\
\text { Longitudinal prospective study in psychiatric outpatients } \\
\qquad(n=120)\end{array}$ & $28.6 \%$ \\
\hline $\begin{array}{c}\text { Rajpur et al., } 1984 \\
\text { Epidemiological study in the community } \\
(n=138 \text { new cases of parkinsonism })\end{array}$ & $7.2 \%$ (of 138 ) \\
\hline $\begin{array}{l}\text { Bower et al., } 1999 \\
\text { Epidemiological study in the community } \\
(n=364 \text { incident cases of parkinsonism) }\end{array}$ & $20 \%$ (of 364$)$ \\
\hline $\begin{array}{c}\text { Baldereschi et al., } 2000 \\
\text { Longitudinal study in the community } \\
\text { ( } n=3084 \text { of which } n=68 \text { had parkinsonism) }\end{array}$ & $10 \%$ (of 68 cases) \\
\hline $\begin{array}{c}\text { Rocca et al., } 2001 \\
\text { Epidemiological study in the community } \\
(n=2739 \text { of which } n=364 \text { with parkinsonism) }\end{array}$ & $20 \%$ (of 364 ) \\
\hline $\begin{array}{c}\text { Benito-Leon et al., } 2004 \\
\text { Epidemiological study in community } \\
(n=3813 \text {, of which } n=68 \text { parkinsonism })\end{array}$ & $32.3 \%$ (of 68 ) \\
\hline $\begin{array}{l}\text { De Lau et al., } 2004 \\
\text { Prospective community population cohort } \\
\qquad(n=6839)\end{array}$ & $12 \%$ \\
\hline $\begin{array}{l}\text { Munhoz et al., } 2010 \\
\text { Cohort study in outpatient service } \\
\qquad(n=1528)\end{array}$ & $7.9 \%$ \\
\hline $\begin{array}{l}\text { Seijo-Martinez et al., } 2011 \\
\text { Community-based survey } \\
\qquad(n=41)\end{array}$ & $31.7 \%$ \\
\hline $\begin{array}{l}\text { Bondon-Guitton et al., } 2011 \\
\text { French Pharmacovigilance Database } \\
\qquad(n=20,855)\end{array}$ & $0.7 \%$ \\
\hline
\end{tabular}


Table 1. Cont.

\begin{tabular}{|c|c|}
\hline Study * & Incidence of DIP \\
\hline $\begin{array}{l}\text { Savica et al., } 2013 \\
\text { Cohort Study in community population } \\
\qquad(n=542)\end{array}$ & $6.6 \%$ \\
\hline $\begin{array}{l}\text { Savica et al., } 2017 \\
\text { Epidemiological study in community population }(n=906)\end{array}$ & $11.9 \%$ \\
\hline $\begin{array}{l}\text { Vale et al., } 2018 \\
\text { Cross-sectional study in community population }(n=610)\end{array}$ & $12.3 \%$ \\
\hline $\begin{array}{c}\text { Druschky et al., } 2020 \\
\text { German Pharmacovigilance Database } \\
(n=340,099)\end{array}$ & $0.08 \%$ \\
\hline $\begin{array}{l}\text { De Germay et al., } 2020 \\
\text { WHO Pharmacovigilance Database } \\
\qquad(n=9,009,107)\end{array}$ & $0.05 \%$ \\
\hline $\begin{array}{c}\text { Han et al., } 2019 \\
\text { Korean Health Insurance Review and Assessment Service } \\
\text { Database } \\
(n=\text { circa } 50 \text { million })\end{array}$ & $8.69 / 100,000$ \\
\hline $\begin{array}{l}\text { Fleury et al., } 2018 \\
\text { Retrospective Incidence study in community population } \\
(n=2312)\end{array}$ & $2.5 / 100,000$ \\
\hline
\end{tabular}

Most published studies in community or general population settings have reported DIP to be the second (or less frequently third) most common cause of parkinsonism after IPD, especially in the older population, ranging from $2 \%$ to $76 \%$ of all cases of parkinsonism [5,9-25]. However, when a large database of over 20000 cases of druginduced side-effects over a 17-year period was examined in one French study, the rate of DIP was found to be of $0.7 \%$ [26]. In a recent pharmacovigilance study using the World Health Organisation (WHO) database between 2000 and 2017, DIP was reported in $0.05 \%$ across age groups, with the highest rates in the over 45 age group [27]. In another pharmacovigilance study involving a database of 245958 patients treated with APs between 2001 and 2016, there were 200 adverse reactions of severe parkinsonism reported, giving an overall rate of $0.08 \%$ [3].

Population studies of prevalence have reported rates of DIP of 9.78/100,000 [28], 4.09-7.02/100,000/year in a period of 6 years [10], 21.7/100,000 [25], 37/100,000 [29] and 0.5/100 [30]. Another study in Sicily over a 4-year period showed a prevalence of $32.7 / 100,000$ [13]. In respect of the annual average incidence of DIP, a population study in Olmsted County, US, reported 3.3/100,000/year [9,23]. Incidence was higher in older age groups, ranging from $9.4 / 100,000$ in the 60-69 age bracket to $29.3 / 100,000$ in the $80-99$ age bracket [9]. A study in Korea found an incidence rate of $8.69 / 100,000$ over a three-year period [28], with incidence increasing with age up until the age bracket 75-79y (higher in women than men), and decreasing slightly from age 80. Finally, in a study from Taiwan using data from the National Health Insurance Research Database over the period 2000-2012, the incidence of DIP was found to be of 762.2/100,000 in patients who had taken sulpiride (a highly selective D2R antagonist) for the management of gastro-oesophageal reflux disorder, compared to those who were not treated with this drug [31]. When looking at age groups, the Olmsted study showed an increasing incidence of DIP from age 60 , with the highest incidence in women in the age group 80-89 [14]: 31.8/100,000/year in men and 60.8/100,000 in women. In a Swiss study, the crude annual incidence of DIP was $2.5 / 100,000$ [25]. An incident rate of $76 \%$ was reported in a study of AIP in Alzheimer's disease patients [32]. 
Most studies report that increasing age (for both sexes) and female gender are more frequently associated with incidence and prevalence of DIP [8-10,14,16,17,23,25-28,31,33]. However, the vast majority of these studies include all drug groups associated with DIP, hence it is difficult to ascertain the precise prevalence and incidence of AIP.

The frequency of AIP in nursing home settings is thought to be under-reported. In a small study, 23 out of 27 (85.1\%) residents on APs showed parkinsonism compared to 43 out of 73 of those not on APs [34], whilst in another study in New York City, the rate of drug-induced tremor in 397 nursing home residents was found to be $3 \%$, although the involved medications were not APs but sodium valproate, lithium, and calcium channel blockers [35]. In the same study, the overall prevalence of DIP was 0.5\% [35]. A similar rate of 3\% DIP in older adults in care settings was reported in another study [36].

\subsubsection{Drugs}

The majority of epidemiological studies do not distinguish, in their results, between drugs causing DIP, thus making it difficult to ascertain an accurate rate of AIP. However, a study reporting on a cohort of 1528 patients with parkinsonism where DIP accounted for $7.9 \%$ of all cases concluded that DIP was caused by APs in $53 \%$ of cases [20]. In another large study using a pharmacovigilance database, DIP was associated with D2R antagonists in $50 \%$ of cases, the rest being associated with other drugs [26].

In relation to types of APs, a recent pharmacovigilance study (involving a database of 245,958 patients treated with APs between 2001 and 2016) found that low-potency FGAs were significantly less often implicated in the causation of AIP $(0.02 \%)$ than SGAs $(0.07 \%)$, and high-potency FGAs $(0.16 \%)$. Among the SGAs, amisulpride and risperidone ranked highest. Phenothiazines showed significantly lower rates of severe parkinsonism $(0.02 \%)$ than butyrophenones $(0.11 \%)$ and thioxanthenes $(0.12 \%)$ [3]. It has also been reported that the risk of AIP with high-dose SGAs does not seem to differ substantially to that from FGAs [37], and that the profile of symptoms SGAs induce is similar to that of FGAs [38]. Sulpiride, risperidone, olanzapine and haloperidol are the most frequently reported APs in AIP [27,28,39]; whilst levosulpiride, metoclopramide, clebopride and itopride, are the most frequently reported gastrokinetic drugs associated with DIP [39,40]. Data from adverse event reporting systems also points towards an increase in DIP over time, at the expense of gastrokinetic drugs and APs [41]. The incidence rates for FGA related AIP in older adults varies from 30\% to $60 \%$ [42]. The incident rates for SGA related AIP is lower. Studies investigating quetiapine reported an incident rate of $6 \%$ [43], and olanzapine reported rates of 5-14\% [44]. The incidence of risperidone induced AIP increased from $6.7 \%$ for $0.5 \mathrm{mg} /$ day to $21.2 \%$ for $2 \mathrm{mg} /$ day [45]. In a retrospective cohort study investigating dementia patients, risperidone and olanzapine taken at $10 \mathrm{mg} /$ day and $2 \mathrm{mg}$ /day respectively, showed a similar risk of parkinsonism compared to FGAs [37]. Considering the effects of different drug groups on the emergence of DIP, it has been suggested that there may be a bimodal pattern of symptom occurrence, with DIP caused by D2R antagonists such as APs and gastrokinetic drugs appearing within 0 to 6 months of treatment commencement; and DIP secondary to calcium channel blockers arising after 9-12 months of treatment $[46,47]$. This suggests that AIP arises soon after treatment is started. See Table 2 for the different AP groups, and Table 3 for studies on drugs associated with DIP and their respective frequencies. 
Table 2. Groups of antipsychotic and other anti-D2R drugs.

\begin{tabular}{|c|c|c|}
\hline & First Generation APs & Second Generation APs \\
\hline Phenothiazines & $\begin{array}{c}\text { Chlorpromazine } \\
\text { Promazine } \\
\text { Levomepromazine } \\
\text { Triflupromazine } \\
\text { Mesoridazine } \\
\text { Thioridazine } \\
\text { Fluphenazine (HP) } \\
\text { Perphenazine } \\
\text { Prochlorperazine (HP) } \\
\text { Trifluoperazine (HP) }\end{array}$ & \\
\hline Butyrophenones (HP) & $\begin{array}{c}\text { Haloperidol } \\
\text { Benperidol } \\
\text { Droperidol }\end{array}$ & \\
\hline Thioxanthenes & $\begin{array}{c}\text { Chlorprothixene } \\
\text { Clopenthixol (HP) } \\
\text { Flupenthixol (HP) } \\
\text { Thiothixene } \\
\text { Zuclopenthixol (HP) }\end{array}$ & \\
\hline Benzamides & $\begin{array}{c}\text { Sulpiride } \\
\text { Tiapride } \\
\text { Veralipride } \\
\text { Levosulpiride } \\
\text { Metoclopramide } \\
\text { Mosapride } \\
\text { Lisepride } \\
\text { Clebopride } \\
\end{array}$ & $\begin{array}{l}\text { Amisulpiride (FD) } \\
\text { Remoxipride (FD) } \\
\text { Sultopride } \\
\text { Itopride }\end{array}$ \\
\hline Indole derivatives & $\begin{array}{l}\text { Oxypertine } \\
\text { Molindone }\end{array}$ & $\begin{array}{l}\text { Ziprasidone } \\
\text { Lurasidone }\end{array}$ \\
\hline Diphenylbutylpiperidines & Pimozide (HP) & \\
\hline Other & & $\begin{array}{c}\text { Loxapine } \\
\text { Clozapine (FD) } \\
\text { Olanzapine } \\
\text { Quetiapine (FD) } \\
\text { Asenapide } \\
\text { Clotiapine } \\
\text { Zotepine } \\
\text { Paliperidone } \\
\text { Sertindole } \\
\text { Aripiprazole }\end{array}$ \\
\hline
\end{tabular}

D2R = Dopamine 2 receptor; AP = Antipsychotic; HP = High Potency, FD = Fast Dissociation .

Table 3. Studies highlighting specific drugs associated with Drug-induced Parkinsonism and their frequencies.

\begin{tabular}{|c|c|c|}
\hline $\begin{array}{c}\text { Study } \\
(3,20,26,27,38,40,41)\end{array}$ & Drug Class & $\%$ and Number of Subjects \\
\hline \multirow{3}{*}{ Munhoz et al., 2010} & Antipsychotics & $52.9 \% n=74$ \\
\hline & Calcium Channel Blockers & $35.7 \% n=50$ \\
\hline & Other drug classes & $11.4 \% n=16$ \\
\hline \multirow{6}{*}{$\begin{array}{l}\text { Bondon-Guitton et al., } \\
\qquad 2011\end{array}$} & \multirow{6}{*}{$\begin{array}{c}\text { Central dopaminergic antagonists } \\
\text { Antidepressants } \\
\text { Calcium Channel Blockers } \\
\text { Peripheral dopaminergic } \\
\text { antagonists } \\
\text { H1 antihistamines } \\
\text { Miscellaneous drugs }\end{array}$} & $49 \% n=128$ \\
\hline & & $8 \% n=21$ \\
\hline & & $5 \% n=13$ \\
\hline & & $4.6 \% n=12$ \\
\hline & & $4.6 \% n=12$ \\
\hline & & $28.7 \% n=75$ \\
\hline \multirow{4}{*}{ Druschky et al., 2020} & Antipsychotic Drugs: & \\
\hline & -First Generation-Low Potency & $0.024 \% n=17$ \\
\hline & -First Generation-High Potency & $0.159 \% n=78$ \\
\hline & -Second Generation & $0.073 \% n=139$ \\
\hline
\end{tabular}


Table 3. Cont.

\begin{tabular}{|c|c|c|}
\hline $\begin{array}{c}\text { Study } \\
(3,20,26,27,38,40,41)\end{array}$ & Drug Class & $\%$ and Number of Subjects \\
\hline Munhoz et al., 2017 & $\begin{array}{c}\text { Classic neuroleptics } \\
\text {-Haloperidol } \\
\text {-Levomepromazine } \\
\text {-Chlorpromazine } \\
\text {-Thioridazine } \\
\text { Second-generation neuroleptics } \\
\text {-Risperidone } \\
\text {-Olanzapine } \\
\text { Calcium channel blockers } \\
\text {-Flunarizine } \\
\text {-Cinnarizine }\end{array}$ & $\begin{array}{c}n=78 \\
48.7 \% n=38 \\
24.4 \% n=19 \\
17.9 \% n=14 \\
9 \% n=7 \\
n=21 \\
81 \% n=17 \\
19 \% n=4 \\
n=58 \\
65.5 \% n=38 \\
34.5 \% n=20\end{array}$ \\
\hline De Germay et al., 2020 & $\begin{array}{l}\text { Risperidone } \\
\text { Haloperidol } \\
\text { Aripiprazole } \\
\text { Olanzapine } \\
\text { Valproic acid } \\
\text { Quetiapine } \\
\text { Sulpiride } \\
\text { Clozapine } \\
\text { Metoclopramide } \\
\text { Paliperidone }\end{array}$ & $\begin{array}{l}14 \% n=637 \\
9.4 \% n=428 \\
7.2 \% n=330 \\
6.2 \% n=283 \\
5.7 \% n=262 \\
4.0 \% n=184 \\
3.6 \% n=164 \\
3.5 \% n=160 \\
3.5 \% n=160 \\
3.3 \% n=151\end{array}$ \\
\hline Oh et al., 2018 & $\begin{array}{l}\text { Levosulpiride } \\
\text { Metoclopramide } \\
\text { Clebopride } \\
\text { Itopride }\end{array}$ & $\begin{array}{l}78.2 \% n=54 \\
11.58 \% n=8 \\
7.24 \% n=5 \\
2.89 \% n=2\end{array}$ \\
\hline Kim S et al., 2019 & $\begin{array}{c}\text { Typical Antipsychotics } \\
\text { Atypical Antipsychotics } \\
\text { Gastrokinetic }\end{array}$ & $\begin{array}{c}0.3 \% n=15 \\
0.8 \% n=45 \\
22.2 \% n=1222\end{array}$ \\
\hline
\end{tabular}

\subsubsection{Risk Factors}

In addition to age over 60 and female gender, a number of studies have suggested that other patient and drug-related factors can be associated with an increased risk of developing AIP (Table 4). Patient-related factors are organic brain damage, learning disability, dementia, IPD, hypertension, organic personality disorder, schizophrenia, mania, depression or anxiety, HIV infection, non-European ancestry, and presence of HLA-B44 [3,31,33,47-49]; whilst drug-related causes are high potency APs, higher dosage of APs, and long-term exposure to APs $[3,33]$. The diagnosis of DIP has also been reported to triple the lifetime risk of developing IPD [50,51], whilst the relative risk of developing IPD was found in one study to be of 24.3 (CI 95\%) [52].

Table 4. Risk factors for AIP.

\begin{tabular}{cc}
\hline Patient-Related & Drug-Related \\
\hline Age $>60$ & High potency first generation antipsychotics \\
\hline Female Gender & $\begin{array}{c}\text { High dose of antipsychotics } \\
\text { (first and second generation) }\end{array}$ \\
\hline Organic Brain Damage & \\
\hline Intellectual Disability & \\
\hline Dementia & \\
\hline Idiopathic Parkinson's Disease & \\
\hline Hypertension & \\
\hline
\end{tabular}


Table 4. Cont.

\begin{tabular}{l}
\hline Non-European ancestry \\
\hline HIV infection \\
\hline HLA-B44 \\
Schizophrenia, depression \\
$\begin{array}{l}\text { AIP = Antipsychotic-Induced Parkinsonism; HIV = Human Immunodeficiency Virus; HLA = Human Leukocyte } \\
\text { Antigen. }\end{array}$
\end{tabular}

\subsection{Pathophysiology}

It has been long established that APs block cerebral D2Rs in the brain, especially in the striatum and mesocortex, causing a state equivalent to dopamine deficiency which is responsible for the parkinsonism [1,47]. This is the mode of action of high-potency FGAs, due to their high antagonistic affinity for D2Rs in the striatum (e.g., the butyrophenone haloperidol). However, the pathophysiology of AIP is yet to be fully understood [33]. Dopamine blockade by itself does not account for AIP completely, as symptoms of parkinsonism may last for weeks to months, whereas its effects on psychotic symptoms only last for several hours $[8,53]$. It is not well understood why AIP occurs after days to weeks of being exposed to an AP, whilst D2R blockade occurs minutes after exposure [47].

It has been proposed that the rate at which APs dissociate from the D2R (dissociation constant), may predict their likelihood to cause parkinsonism [54-56]; hence APs producing a transient D2 blockade (fast dissociation), such as clozapine and quetiapine, would allow the physiological stimulation of the D2R by endogenous dopamine $[47,55,56]$ reducing the effects on the motor system whilst maintaining antipsychotic action [56]. This principle of transient occupation of D2Rs has been well demonstrated in the case of clozapine [56], and has been used to develop extended AP dosing (e.g., every other day) for other APs with slow dissociation with safe and effective clinical results [56,57]. It has also been suggested that D2R and serotonin 5-HT2A receptor blockade may reduce the risk of AIP [47]. Many SGAs block both types of receptor, and this dual effect may account for the lower reported risk of AIP associated with these agents [47,58]. Blockade of both dopaminergic and cholinergic transmission may also decrease the risk of AIP [47], as high potency FGAs such as haloperidol have little anticholinergic activity and are more likely to cause AIP compared to lower potency first generation APs (such as chlorpromazine) that have significant anticholinergic activity and less propensity to cause AIP [47]. However, studies on clozapine have shown that the effects on these other neurotransmitter systems are not the explanation for its lack of propensity to cause parkinsonism, whilst fast dissociation is [56].

Further explanations for the observation that D2 blockade by itself does not account for AIP completely come from studies of gene expression after AP intake, which have shown different patterns of gene expression in patients with extrapyramidal side-effects (EPS), including parkinsonism [59-62]. In particular, pathways involving mTOR and NF-kB kinases have been described as playing a key role in AP-induced EPS including AIP [59,60]. Further recent studies examining the effects of single nucleotide polymorphisms (SNPs) affecting transcription factor binding sites (TFBS) in response to treatment with APs, showed that two SNPs in two genes, LSMAP and ABL1, were significantly associated with AP-induced EPS [62], as did the mTOR pathway-related genes AKT1 and RPTOR [61].

Drugs that block D2Rs may also have a direct neurotoxic effect on dopaminergic neurons, and this may also explain why some patients continue to experience parkinsonism many months following discontinuation of the offending drug (around $20 \%$ of patients) $[8,33,63]$. This neurotoxic hypothesis is further supported by the finding of an increased long-term risk of developing IPD in older patients with a past history of exposure to APs [50], and by the findings in animal models of neuronal death with exposure to APs, likely via inhibition of the mitochondrial respiratory chain, increased D2R turnover, and free radical production $[8,63]$. It has also been proposed that parkinsonism occurring after a short exposure to APs may be related to an underlying dysfunction in the nigrostri- 
atal dopaminergic pathway as ascertained through dopamine transporter (DaT) Positron Emission Tomography (PET) scanning [64]. This is highly relevant in older patients [8].

An MRI study found that patients with DIP presented with disruption of the white matter microstructure (measured by fractional anisotropy and mean diffusivity) compared to control subjects but not to IPD patients; and that these abnormalities were correlated with clinical signs of parkinsonism and presence of cognitive dysfunction, independently from exposure time to the offending drug and duration of DIP [65]. White matter abnormalities in frontal and parietal areas were more closely associated with severity of parkinsonism, and it was hypothesized that such abnormalities may disrupt the connections of functionally important basal ganglia-motor/sensory cortical circuits relevant for motor control [65]. Although causality could not be inferred from this study due to its cross-sectional design, it was suggested that microstructural alterations in the white matter may represent a preexisting pathology of DIP, and therefore act as a risk factor for DIP, rather than being a secondary phenomenon of dopamine depleting effects [65]. In addition, a recent study reported that in patients with DIP there was decreased functional connectivity (FC) between the sensorimotor network and widespread cortical regions compared to control subjects [66]. The study also found that FC between the sensorimotor network and the prefrontal cortex correlated negatively with parkinsonian motor severity [66].

\subsection{Clinical Characteristics}

There is no agreed set of diagnostic criteria for DIP. The diagnosis of parkinsonism requires the presence of at least two of four cardinal signs, namely: resting tremor, bradykinesia, rigidity, and impairment of postural reflexes [13,67]. DIP is further defined by a history of symptom-onset after commencing APs or other dopamine-depleting drugs; by an absence of symptoms prior to treatment with these drugs; and by the resolution of symptoms within 6 months of drug withdrawal [14,33].

The most widely used definition of parkinsonism is that of the United Kingdom Parkinson's Disease Society Brain Bank (UKPDSBB) Clinical Diagnostic Criteria [67]. In their Step 1 , they establish that for the diagnosis of a parkinsonian syndrome, bradykinesia must be present, as well as at least one of the following signs: muscular rigidity, a $4-6 \mathrm{~Hz}$ resting tremor, or postural instability not caused by primary visual, vestibular, cerebellar, or proprioceptive dysfunction. Step 2 provides exclusion criteria for IPD, including neuroleptic treatment at time of onset, and Step 3 provides prospective supportive positive criteria for IPD.

The Diagnostic and Statistical Manual of Mental Disorders, fifth edition (DSM-V) [68] defines DIP as the presence of resting tremor, muscular rigidity, akinesia, or bradykinesia, developing within a few weeks of starting or raising the dosage of a medication (typically an AP or another neuroleptic), or else after reducing the dose of an antiparkinsonian agent. The presence of bradykinesia is not mandatory, in contrast to the UKPDSBB Step 1 Clinical Diagnostic Criteria [67,69].

The Simpson-Angus Scale (SAS) [70] does not consider bradykinesia as an essential sign for diagnosis, but gives a higher importance to rigidity [69]. This scale has been shown to have good internal consistency reliability, and good inter-rater reliability in the assessment of DIP in older patients [71].

\subsubsection{Motor Signs}

Motor features of DIP have been reported to be similar to those of IPD [7,8,51,72-75], presenting in a more symmetrical way, with an upper limb predominance [76], and with less axial impairment [6] compared to IPD. In keeping with this, a PET study of DaT in AIP [77] showed that symmetrical parkinsonism was more frequent in patients with normal uptake in the striatal DaTs.

However, there have been reports of cases of DIP with an asymmetrical presentation $[72,78]$ although it is not clear whether these patients could have emerging IPD. 
It must be noted that the ascertainment of bradykinesia might be difficult in patients with schizophrenia and AIP who have significant negative symptoms [47].

Other studies have reported a greater frequency of concomitant orofacial dyskinesias and of akathisia in cases of DIP compared with IPD [7,8]; absence of resting tremor [8,72]; yet presence of postural tremor [47]. Rabbit syndrome (perioral tremor) is more often associated with AIP [47]. Conversely, amimia has been suggested to be more typical of IPD as well as postural instability [6]. A PET study of DaTs in patients with DIP showed that symmetrical parkinsonism and presence of orofacial dyskinesias were more frequent in patients with normal striatal tracer binding [79].

\subsubsection{Non-Motor Signs}

Given the similarities in the motor manifestations of DIP and IPD, it has been thought that non-motor signs might be worth studying to ascertain whether they can assist in distinguishing them. AIP and IPD can cause non-motor signs and symptoms in older individuals, including sleep disturbances, mood changes, autonomic dysfunction, pain, and cognitive deficits $[4,80]$. Older adults may also have an increased sensitivity to the anticholinergic effects of APs leading to constipation, blurred vision, dry mouth, and urinary retention [81]. Urinary symptoms (urgency, frequency, and nocturia), sleep disturbances (daytime sleepiness, restless legs), concentration problems, sexual dysfunction, and olfactory dysfunction, have all been significantly associated with IPD compared to DIP $[4,6,69,80,82]$. Olfactory impairment, in particular, is very prevalent in IPD [6,82] and represents an early sign of neurodegeneration; but it is not a common symptom of DIP [69], although this has been reported [83]. It has been suggested that olfactory function tests may be a useful tool in the differential diagnosis between DIP and IPD [84], and also in the diagnosis of "masked" IPD in patients with DIP [6] who do not seem to recover after withdrawal of the offending drug. A study combining olfactory function tests and PET scanning of DaTs, found that patients with DIP and abnormal uptake in the putamen also had an abnormal olfactory function, whilst DIP patients with normal putaminal uptake showed olfactory function similar to control subjects [85]. Another study showed that patients with DIP and normal olfactory test scores had normal cardiac iodine-123-metaiodobenzylguanidine (MIBG) uptake, and one patient with reduced olfactory test scores showed reduced cardiac MIBG uptake, suggesting that it might be a case of subclinical IPD [84]. Poorer cognitive functioning has been reported in DIP compared to IPD [84]; whilst in patients with schizophrenia, cognitive disturbance was found to be more common in those with AIP than in those without it [80].

Olfactory dysfunction and REM Sleep Behaviour Disorder are indicators of early neurodegeneration and hence, of pre-motor IPD. Their presence might be a useful predictor of outcome in DIP, in the sense that they might indicate a group of patients at high risk of developing a synucleinopathy such as IPD [6].

\subsection{Investigations}

\subsubsection{Dopamine Transporter Scanning}

Single-photon emission CT (SPECT) or PET, using Iodine-123-Ioflupane as a DaT ligand is a well-established sensitive method to help diagnose IPD and other related synucleinopathies, as it can clearly demonstrate loss of presynaptic DaTs in the striatum (particularly in the putamen) in patients with IPD, reflecting the underlying nigrostriatal pathway degeneration [86]. SPECT DaT radioligands available are Iodine-123-beta-CIT, Iodine-123-IPT, and 99mCT-TRODAT-1. However, SPECT using Iodine-123-Ioflupane (DaTscan) is the only imaging technique approved by the European Medicines Agency in 2000, and the US Food and Drug Administration in 2011 to differentiate essential tremor and diseases related to PD [86-88]. Since DIP is considered not to be related to nigrostriatal pathway degeneration, this modality of brain scanning has been used to distinguish cases of DIP (normal DaT striatal uptake of tracer) from IPD (reduced striatal uptake) $[7,73,75,77,79,82,85,87-97]$. Even in the preliminary stages of IPD, DaT 
uptake in the striatum can be significantly decreased leading to an abnormal DaT scan [98]. By contrast, DIP is considered a form of postsynaptic parkinsonism via D2R blockade and has negligible affinity for DaT, which leads to a normal DaT scan in pure DIP $[82,88]$. A meta-analysis reported that pooled accuracy measures to differentiate IPD from vascular parkinsonism and DIP were relatively high, with a sensitivity of $85 \%$ and a specificity of $80 \%$ [87].

A DaT scan can also differentiate between true DIP and individuals with a subclinical form of IPD whose motor symptoms have been unmasked by APs $[7,73,80,88,98]$. Motor symptoms in IPD do not become manifest until $60-80 \%$ of dopaminergic neurons degenerate, so an asymmetrical decrease of DaT uptake in the striatum suggests that these patients may have instead IPD or a subclinical form of the disease [98]. This might be particularly important in cases of DIP that persist over time despite discontinuation of the offending drug.

Certain drugs can interfere with DaT binding and make DaT scans difficult to interpret. This is especially noticeable with dopaminergic stimulants (cocaine, amphetaminerelated compounds, methylphenidate, and modafinil) and depleters, which should be stopped prior to scan [88]. Certain aminergic antidepressants, such as sertraline, citalopram, imipramine, and duloxetine can also interfere with DaT binding, but to a much lesser degree [88].

An alternative imaging method to DaT scan is the study of the vesicular monoamine transporter type 2 (VMAT2), using PET and the radioligand [11C](+)-dihydrotetrabenazine which binds to this transporter molecule. This imaging modality has been suggested as an alternative to DaT scan, as the VMAT2 is less modulated by drugs that affect dopaminergic transmission in the brain [51]. In a study using PET to measure binding to VMAT2 in patients with schizophrenia with chronic AIP, patients with schizophrenia without AIP, normal controls, and patients with IPD, observed that in the group with AIP there was a dichotomous striatal binding to VMAT2, with a spared binding subgroup, and a low binding one [51]. In the subgroup with low binding, this reduction was found to be asymmetrical but without the gradient of maximal involvement of the posterior putamen which is typical of IPD [51]. This led the authors to suggest that in a fraction of patients with chronic AIP, VMAT2 binding differs from that of IPD, and might indicate a drug-induced axonopathy that results in synaptic dysfunction [51]. Further, anosmia was found to be the only non-motor parameter that matched this abnormal striatal binding to VMAT2 [51].

\subsubsection{Cardiac 123I-MIBG (Iodine-123-Meta-Iodobenzylguanidine) Scintigraphy}

Cardiac MIBG scintigraphy is not widely used or funded as a test for IPD in most countries, which may be the reason for the scarcity of studies using this diagnostic technique [82]. Nevertheless, it has been proposed to help diagnose IPD by means of looking at cardiac postganglionic autonomic involvement [99]. Cardiac uptake of the synthetic norepinephrine analog 123I-MIBG depends on the integrity of postganglionic sympathetic neurons, and since $\alpha$-synuclein-dependent neurodegeneration in IPD affects both pre- and postganglionic autonomic neurons, cardiac 123I-MIBG uptake is impaired [99].

Cardiac MIBG uptake is reported to be significantly reduced in patients with IPD due to sympathetic dysfunction, whilst it is typically normal in those with DIP. This suggests that there is an intact sympathetic function in DIP [100]. A study in patients with DIP, IPD, and control subjects, reported that DIP patients had normal cardiac MIBG scintigraphy compared to those with IPD [100]. In the same study, two patients with DIP and reduced MIBG uptake, showed persistent parkinsonism which responded to levodopa [100].

Patients with DIP and normal olfactory tests have normal cardiac MIBG scintigraphy [84]. It has also been reported that patients with DIP who also have olfactory problems at baseline have altered cardiac MIBG scintigraphy [84,101], indicating that this subset of DIP patients may in fact be suffering from preclinical IPD. 


\subsubsection{Substantia Nigra Ultrasonography}

Transcranial ultrasonography (TCS) has been considered for its potential in differentiating DIP from IPD. It is a non-invasive, inexpensive, relatively accessible, and radiation free form of investigation. TCS has been widely used to diagnose IPD and also to differentiate Parkinson's types [40,102]. A study investigated whether substantia nigra (SN) and lenticular nucleus (LN) echogenicity through TCS could differentiate between DIP and IPD [91]. Although their results did not show significant differences, the authors still believed it to be a valid technique, and attributed the lack of significant results to a small sample size. Another study used TCS to measure SN echogenicity and hypothesized that it might be useful in detecting patients with underlying dopaminergic degeneration in those with DIP and at higher risk of not improving following withdrawal of the parkinsonism inducing drug [103]. Results showed that it would be a useful prognostic marker in overall clinical assessment for the estimation of recovery rate in the setting of suspected DIP. However, the paper acknowledged the limitations of this imaging modality compared to DaT radiotracers, and suggested that TCS should not be used to establish a definite diagnosis of the underlying pathology [103].

TCS was used in other studies to measure SN echogenicity in IPD, DIP and control groups $[40,104]$. Results showed that TCS SN echogenicity was significantly increased in IPD, while DIP $[40,104]$ and controls [40] had similar SN echogenicity. The authors concluded that $\mathrm{SN}$ echogenicity could be a useful instrument to differentiate IPD from DIP in clinical situations using TCS [40]. However, this study used gastroprokinetic-drugs to induce dopamine blockade, rather than APs.

\subsubsection{Others}

Magnetic resonance imaging 3-T of the Nigrosome 1 has also been suggested to be helpful in the differential diagnosis of IPD and DIP with high accuracy and may help to screen patients who need DaT imaging in those suspected of having DIP [105].

See Tables 5 and 6 for the main differences between DIP and IPD in terms of clinical signs and results of investigations, and Table 7 for the relevant investigation studies with their main findings.

Table 5. Comparison of DIP vs. IPD symptomatology and investigation findings.

\begin{tabular}{ccc}
\hline & AIP & IPD \\
\hline Symptoms & General & \\
\hline Onset & More symmetrical & More asymmetrical \\
\hline Course & Acute or subacute & Chronic \\
\hline & $\begin{array}{c}\text { Reversible after withdrawal of } \\
\text { drug }\left(^{*}\right)\end{array}$ & Progressive \\
\hline Upper Limb Predominance & Motor & $\uparrow \downarrow$ \\
\hline Axial Impairment & $\uparrow$ & $\uparrow$ \\
\hline Oro-facial dyskinesias & $\downarrow$ & $\downarrow$ \\
\hline Akathisia & $\uparrow$ & $\downarrow \uparrow$ \\
\hline Resting Tremor & $\uparrow$ & $\downarrow$ \\
\hline Postural Tremor & $\downarrow$ & $\downarrow$ \\
\hline Perioral Tremor & $\uparrow$ & $\uparrow$ \\
\hline Amimia & $\uparrow$ & $\uparrow$ \\
\hline Postural instability & $\downarrow$ & $\downarrow$ \\
\hline
\end{tabular}


Table 5. Cont.

\begin{tabular}{ccc}
\hline & AIP & IPD \\
\hline & Non-motor & \\
\hline Mood Changes & $\uparrow$ & $\uparrow$ \\
\hline Autonomic Dysfunction & $\uparrow$ & $\uparrow \uparrow$ \\
\hline Cognitive Deficits & $\uparrow$ & $\uparrow \uparrow$ \\
\hline Pain & $\uparrow$ & $\uparrow$ \\
\hline Sleep disturbances & $\uparrow$ & $\uparrow \uparrow \uparrow$ \\
\hline Olfactory dysfunction & $\downarrow \downarrow \downarrow$ & $\uparrow \uparrow \uparrow$ \\
\hline Urinary symptoms & $\uparrow$ & $\uparrow \uparrow$ \\
\hline Concentration Problems & $\uparrow$ & $\uparrow \uparrow \uparrow$ \\
\hline Sexual dysfunction & $\uparrow$ & $\uparrow \uparrow$
\end{tabular}

$\uparrow=$ Increased frequency, $\downarrow$ = Decreased frequency; AIP = Antipsychotic-Induced Parkinsonism; IPD = Idiopathic Parkinson's Disease; * Unless associated neurodegeneration of striato-nigral pathway is present.

Table 6. Investigation findings in DIP vs. IPD.

\begin{tabular}{ccc}
\hline Investigation & AIP & IPD \\
\hline DaT Scan & Normal $\left(^{*}\right)$ & $\begin{array}{l}\text { Abnormal/Frequently } \\
\text { asymmetrical findings }\end{array}$ \\
\hline Cardiac MIBG Scintigraphy & Normal $\left(^{*}\right)$ & Abnormal \\
\hline TCS of Substantia Nigra & Normal $\left(^{*}\right)$ & Abnormal \\
\hline $\begin{array}{l}\text { AIP = Antipsychotic-Induced Parkinsonism; IPD = Idiopathic Parkinson's Disease; DaT = Dopamine Transporter; } \\
\text { MIBG = meta-iodobenzylguanidine; TCS }=\text { Transcranial Ultrasonography. }{ }^{*} \text { Unless associated neurodegeneration }\end{array}$
\end{tabular}

Table 7. Studies on investigations for the differential diagnosis of DIP vs. IPD.

\begin{tabular}{|c|c|c|}
\hline Study * & $\mathbf{N}$ & Conclusions \\
\hline \multicolumn{3}{|l|}{$\begin{array}{l}\text { DAT } \\
\text { Scanning }\end{array}$} \\
\hline $\begin{array}{l}\text { Lorberboym } \\
\text { et al., } 2006\end{array}$ & 30 & $\begin{array}{l}\text { [123I]FP-CIT SPECT can help distinguish whether DIP is drug-induced or } \\
\text { an exacerbation of subclinical IPD. }\end{array}$ \\
\hline $\begin{array}{l}\text { Diaz-Corrales } \\
2010\end{array}$ & 79 & $\begin{array}{l}\text { DIP and IPD are clinically difficult to differentiate, and can be improved by } \\
\text { [123I]FP-CIT SPECT imaging. }\end{array}$ \\
\hline Shin et al., 2015 & 92 & $\begin{array}{c}\text { Symmetrical parkinsonism was more prevalent and duration of drug } \\
\text { exposure before the onset of parkinsonism shorter for patients with normal } \\
\text { vs. abnormal [18F]FP-CIT PET scans. }\end{array}$ \\
\hline $\begin{array}{l}\text { Tinazzi et al., } \\
\qquad 2009\end{array}$ & 19 & $\begin{array}{c}\text { [123I]FP-CIT SPECT imaging helps identify subjects with DIP secondary to } \\
\text { a loss of dopamine nerve terminals in the context of a progressive } \\
\text { degenerative parkinsonism. }\end{array}$ \\
\hline Bovi et al., 2010 & 48 & $\begin{array}{l}\text { Patients with DIP and pathological putamen uptake had abnormal olfactory } \\
\text { function. Smell deficits in DIP patients may be more associated with } \\
\text { dopaminergic loss than drug-mediated dopamine receptor blockade. }\end{array}$ \\
\hline $\begin{array}{l}\text { Tinazzi et al., } \\
\quad 2012\end{array}$ & 97 & $\begin{array}{c}\text { D2-receptor blockade may accompany a dopamine nigrostriatal terminal } \\
\text { defect, as assessed by [123I]FP-CIT SPECT abnormalities, in an applicable } \\
\text { proportion of DIP patients. }\end{array}$ \\
\hline Jin et al., 2013 & 98 & $\begin{array}{c}\text { Dual-phase }[18 \mathrm{~F}] \mathrm{FP}-\mathrm{CIT} \text { PET imaging helps demonstrate striatal DAT loss } \\
\text { in neurodegenerative parkinsonism. }\end{array}$ \\
\hline Park et al., 2014 & 33 & $\begin{array}{l}\text { [18F]FP-CIT PET imaging useful to differentiate parkinsonism in patients } \\
\text { with inconclusive parkinsonian features, except in patients who show } \\
\text { atypical features or who eventually progress to PD. }\end{array}$ \\
\hline
\end{tabular}


Table 7. Cont.

\begin{tabular}{|c|c|c|}
\hline Study ${ }^{*}$ & $\mathbf{N}$ & Conclusions \\
\hline \multicolumn{3}{|l|}{$\begin{array}{l}\text { DAT } \\
\text { Scanning }\end{array}$} \\
\hline $\begin{array}{l}\text { Sadasivan et al., } \\
\qquad 2015\end{array}$ & 65 & $\begin{array}{c}\text { [18F]FP-CIT PET can significantly impact patient clinical management in } \\
\text { those with clinically uncertain parkinsonian syndromes in a tertiary referral } \\
\text { center. }\end{array}$ \\
\hline Bega et al., 2015 & 83 & $\begin{array}{c}\text { [18F]FP-CIT PET had a significant impact on clinical diagnosis and } \\
\text { management. }\end{array}$ \\
\hline Hong et al., 2016 & 50 & $\begin{array}{l}\text { Persistent DIP in patients with visually normal [18F]FP-CIT PET DAT } \\
\text { imaging may be associated with subtle reduction of DAT activity. }\end{array}$ \\
\hline $\begin{array}{l}\text { Bhattacharjee } \\
\text { et al., } 2017\end{array}$ & 48 & $\begin{array}{l}\text { Compliance of the [123I]FP-CIT SPECT imaging with the existing standard } \\
\text { guidelines is good and influences the clinical diagnosis and management in } \\
23 \% \text { of the patients with parkinsonism. }\end{array}$ \\
\hline Vlaar et al., 2008 & 248 & $\begin{array}{l}\text { [123I]FP-CIT SPECT is accurate to differentiate patients with IPD from those } \\
\text { with essential tremor (ET), and IPD from vascular parkinsonism (VP) and } \\
\text { DIP. }\end{array}$ \\
\hline \multicolumn{3}{|r|}{ VMAT using PET and radioligand } \\
\hline $\begin{array}{l}\text { Galoppin et al., } \\
2020\end{array}$ & 45 & $\begin{array}{l}\text { Striatal VMAT2 binding is abnormal in a fraction of chronic DIP cases and } \\
\text { differs in spatial distribution from PD. }\end{array}$ \\
\hline \multicolumn{3}{|r|}{ Cardiac Scintigraphy } \\
\hline Lee et al., 2006 & 20 & $\begin{array}{l}\text { MIBG uptake was not different between the DIP patients and controls. Two } \\
\text { DIP patients whose MIBG uptake was significantly reduced showed } \\
\text { persistent parkinsonism and responded dramatically to levodopa. }\end{array}$ \\
\hline Lee et al., 2007 & 15 & $\begin{array}{l}\text { An olfactory function test may be useful to detect DIP unrelated to PD and } \\
\text { to identify patients with DIP who have subclinical PD. }\end{array}$ \\
\hline \multicolumn{3}{|c|}{ Transcranial Ultrasonography of the Substantia Nigra } \\
\hline Oh et al., 2018 & 193 & $\begin{array}{l}\text { SN echogenicity on TCS could help differentiate PD from DIP in clinical } \\
\text { situations. Pure DIP and unmasked PD exhibited different SN echogenicity } \\
\text { patterns. Early SN echogenicity findings on TCS could be used as a } \\
\text { biomarker to predict clinical prognosis of DIP. }\end{array}$ \\
\hline $\begin{array}{l}\text { López-Sendón } \\
\text { Moreno et al., } \\
2016\end{array}$ & 60 & $\begin{array}{l}\text { SN hyperechogenicity assessed with TCS is a valid prognostic marker in the } \\
\text { setting of suspected DIP. }\end{array}$ \\
\hline \multicolumn{3}{|c|}{$\begin{array}{l}\mathrm{N}=\text { number of subjects; DIP = Drug-induced Parkinsonism; ET = Essential Tremor; FP-CIT = N-3-fluoropropyl- } \\
\text { 2beta-carbomethoxy-3beta-4-iodophenyl Tropane; F18 = Fluorine-18; IPD = Idiopathic Parkinson's disease; MIBG } \\
=123 \mathrm{I}-\text { metaiodobenzylguanidine; PET = Positron Emission Tomography; SN = Substantia Nigra; SPECT = } \\
\text { Single-Photon Emission Computerized Tomography; TCS = Transcranial Ultrasonography; VMAT2 = Vesicular } \\
\text { Monoamine Transporter 2; VP = Vascular Parkinsonism; 123I = Iodine-123. * 40, 51, 73, 75, 77, 79, 84, 85, 90, 91, 92, } \\
\text { 93, 94, 95, 96, 97, 100,102, 103. }\end{array}$} \\
\hline
\end{tabular}

\section{Management of AIP}

The management of AIP in older adults generally follows much of the same principles as in working age adults, and is similar to that of other drugs that can cause parkinsonism. There appears to be a significant lack of randomised controlled trials (RCTs) looking at the management of AIP in adults across all age groups, and thus there is a lower level of evidence base when it comes to recommended treatment options. Prior to considering the treatment of AIP, it would be important to remember that prevention is better than cure $[69,106]$; in particular, by evaluating the risk vs. benefit of antipsychotic medication prior to prescribing [80], and ensuring that the lowest effective dose is used whilst monitoring closely for signs of parkinsonism in high risk groups such as the elderly $[7,106]$. If an older patient develops symptoms of AIP, it would be prudent to explore whether these symptoms affect their quality of life and activities of daily living; only then should AIP be treated $[8,80]$. Often, milder cases of AIP do not warrant immediate intervention. The following interventions have been suggested: 


\subsection{Reduce the Antipsychotic Dose}

If an intervention is required, the most appropriate first line approach is to reduce the administration of the AP to the lowest effective dose $[5,88,107]$. One study in patients with very late onset schizophrenia-like psychosis has shown that whilst low dose (100 mg/day) amisulpride could cause a moderate increase in EPS, this was not frequent or severe enough to affect compliance or the benefits of treatment in these patients [108]. This would suggest that in older adults, an initial lower AP dose would be more suitable. This has been confirmed in another recent study of safer prescribing of risperidone for psychosis in Alzheimer's disease [109]. This study argues for age and Mini-Mental State Examination (MMSE) related dose reductions to avoid treatment emergent EPS (including parkinsonism), with a pragmatic approach of "starting low and going slow", whilst preserving clinical efficacy [109]. Reduction of antipsychotic dose is often neglected, with one study showing that in a third of older patients prescribed anticholinergic medication for AIP there had been no attempt to reduce their AP dose [110].

\subsection{Stop the Antipsychotic}

Wherever possible, it would be recommended to stop the offending drug $[69,88,111]$. Because APs have long half-lives, the improvement in AIP will not be immediate [107]. Unfortunately, stopping or reducing the dose of APs can cause a relapse in psychotic symptoms in many patients, posing greater risks to themselves and others.

\subsection{Switch Antipsychotic}

In order to reduce the risk of relapse from stopping the offending AP, it would be prudent to consider switching to an alternative AP [47,98]. SGAs have a reduced propensity to cause parkinsonism at lower doses, with quetiapine and clozapine being deemed the APs of choice $[2,69,88]$. Although evidence has shown that there is little difference in the risk of relapse with immediate versus gradual stopping or switching of APs, most psychiatrists would use a cross-titration strategy. When switching APs, the preferred strategy is usually to cross-titrate medication whereby there is a reduction of the first AP whilst introducing and increasing the second AP [112].

Quetiapine is widely used for psychosis in patients with IPD [82]. Clozapine has the least potential to cause parkinsonism, and is also frequently used to treat psychosis in IPD where it significantly improves psychosis without worsening motor symptoms [113]. The reduced parkinsonian liability of these newer agents derives from their propensity to impose more 5-HT receptor blockade, and in some cases less D2R blockade relative to conventional APs [5]. Unfortunately, due to its significant side-effects, clozapine is often not appropriate to manage psychosis in older patients. Side-effects include agranulocytosis, orthostatic hypotension, tachycardia, myocarditis, metabolic syndrome, and diabetes. Furthermore, older patients are more sensitive to the anticholinergic side-effects of clozapine such as confusion, constipation, and urinary retention [114].

\subsection{Add Anticholinergic}

Adding anticholinergic medication to help with AIP is frequently seen in clinical practice and is supported by anecdotal evidence and small studies $[81,88]$. However, their true efficacy remains uncertain, and is potentially overestimated [72,115]. Anticholinergics are available in oral and parenteral forms [107]. There is little difference between the efficacy of the two most popular anticholinergics: benztropine and trihexyphenidyl [7]. Unfortunately, anticholinergic medication can cause numerous side-effects including urinary retention, angle closure glaucoma, exacerbation of cognitive impairment, worsening tardive dyskinesia, tachycardia, constipation, and increased risk of delirium $[47,81,82,107]$. Such side-effects are more common when prescribed with other medication with potential for anticholinergic adverse effects [116]. Furthermore, anticholinergics may reduce the clinical efficacy of AP agents [107]. Given the significant side-effect burden, and the fact that older patients are more susceptible to them, it is recommended to avoid anticholinergic 
medication to treat AIP in this group [2]. If prescribed, treatment should only be continued if there are signs of clear improvement in the parkinsonism [7], with a typical duration of 3 months [116]. Treatment should be regularly reviewed in order to assess the need for continued use, and it should be eventually stopped. Prophylactic use of anticholinergics is not recommended particularly in older patients [107].

\subsection{Add Amantadine}

Amantadine has antidyskinetic effects and is often used in the treatment of IPD. Its mechanism of action is not fully understood, but it may enhance dopamine release and inhibit its re-uptake into the presynaptic nerve terminal in the striatum [117]. Amantadine has been shown to be beneficial in treating AIP in small clinical trials [8] with some studies finding it to have similar efficacy to anticholinergic medication [118]. However, some of the efficacy data is weak and conflicting [115], with one study showing no difference compared to placebo [119]. It is clear that further robust clinical trials would be required in order to fully ascertain the efficacy of amantadine on older patients with AIP. Amantadine is better tolerated by older patients [2,116] and has been shown to cause fewer side-effects than anticholinergic medication [118]. However, it still can cause some adverse effects including dizziness, insomnia, nausea, dry mouth, blurred vision, and at high doses, it can exacerbate psychosis [116]. Since the drug is excreted primarily in the urine, a lower dosage is required in older people [107].

\subsection{Add L-Dopa or Dopamine Agonist}

For those with AIP who do not have underlying IPD the concurrent use of AP drugs with dopaminergic drugs is generally contraindicated. Levodopa and D2R agonists such as bromocriptine are usually ineffective in treating AIP (due to striatal D2 receptor blockade), and can exacerbate psychosis $[7,88,107]$. Drugs with direct dopaminergic agonist effects such as lisuroride or pergolide can cause confusion in older people [120].

\subsection{Electroconvulsive Therapy}

Beneficial effects of electroconvulsive therapy (ECT) on both psychiatric complications and motor symptoms of IPD have been observed since 1947 [121]. In refractory cases of AIP, where previous management steps have not been successful in ameliorating parkinsonism, case reports suggest that ECT could be an effective option for older patients [122,123], although the evidence base is weak, with no RCTs available. A proposed mechanism of the antiparkinsonian effect of ECT is that it increases the sensitivity of dopamine receptors [121].

\subsection{Physiotherapy}

Physiotherapy may also prove beneficial to patients with AIP, particularly those with disordered posture and gait [69].

\section{Prognosis of AIP}

AIP is generally considered an acute condition having its onset within the first week of starting the antipsychotic [5]. Despite continuation of the offending medication, parkinsonism may gradually abate (and this is suggested to be due to dopamine receptor blockade gradually decreasing over time) [1]. If the offending medication is stopped, AIP gradually disappears in the significant majority of cases, although this can take up to 18 months. This time delay has been related to the possible persistence of some AP drugs in tissue after drug withdrawal [1]. Estimates for the persistence of parkinsonism appear to vary. Most studies focus on DIP more generally rather than specifically to AIP. Estimates on persistence of AIP following discontinuation of APs vary from as low as 1\% [1] up to $20 \%$ [8]. If symptoms persist, it is worth considering whether the patient may have had subclinical IPD before starting treatment. Some have also argued that persistent parkinsonism after drug withdrawal may be due to a direct toxic effect on the dopaminergic 
system [106]. Early differentiation of IPD from AIP is crucial as it has vastly different prognostic implications [111]: receptor imaging studies have shown that over a third of patients with DIP have nigrostriatal dopaminergic dysfunction [73]; and structural imaging studies revealed that microstructural white matter changes are present over various brain regions in patients with DIP [65]. A study measuring functional connectivity (FC) in DIP showed that FC between the sensorimotor network and the cerebellum or prefrontal region was lower in the group of DIP patients with partial recovery following drug withdrawal compared to the complete recovery group; hence, it was a predictor of whether patients with DIP would recover within 3 months of withdrawal of the offending drug [66].

\section{Conclusions}

DIP is a common problem encountered in clinical practice, and is considered to be the second most frequent cause of parkinsonism after IPD, especially in the older population, ranging from $2 \%$ to $76 \%$ of all cases of parkinsonism. APs are one of the most implicated drug groups, with estimations suggesting that over $50 \%$ of subjects over 60 years of age on long-term therapy with APs develop AIP. Low-potency FGAs are significantly less likely to cause AIP than SGAs and high-potency FGAs, and the risk of AIP with high-dose SGAs does not seem to differ substantially from that resulting from FGAs. DIP caused by D2R antagonists such as APs and gastrokinetic drugs seems to appear within 6 months of treatment initiation. The most important risk factors are age over 60 and female gender, whilst other risk factors include organic brain damage, learning disability, dementia, IPD, hypertension, organic personality disorder, and diagnoses of schizophrenia, mania, depression or anxiety, HIV infection, non-European ancestry, and presence of HLA-B44 in addition to use of high potency APs, higher dosage of APs, and long-term exposure to APs. The diagnosis of DIP could triple the lifetime risk of developing IPD. Pathophysiological understanding of DIP is incomplete. The main but not sufficient mechanism is the blockade of D2Rs in the striatum, but it has also been proposed that the rate APs dissociate from the D2R may predict their likelihood to cause parkinsonism; with transient D2 blockade (fast dissociation) being less likely (e.g., clozapine, quetiapine), in addition to gene expression changes induced by APs. D2R antagonists may also have a direct neurotoxic effect on dopaminergic neurons. This may also explain why some patients continue to experience parkinsonism many months following discontinuation of the offending drug (around $20 \%$ of patients). Motor features of AIP are similar to those of IPD; more symmetrical and with an upper limb predominance and with less axial impairment compared to IPD. Concomitant orofacial dyskinesias, akathisia, perioral tremor, and absence of resting tremor are more frequent in AIP than IPD. The most helpful symptoms to differentiate AIP from IPD are olfactory deficits and REM sleep behaviour disorder, as these are invariably more related to neurodegeneration than to side-effects from drugs. The most widely used and diagnostically useful investigation is SPECT/PET imaging of the DaTs. Decreased binding to DaT is a well-established biomarker of IPD and other synucleinopathies, and it is not expected to be found in AIP. Patients with suspected AIP and abnormal DaT scans, especially with asymmetric findings, most likely suffer from IPD. There is a lack of RCTs on the pharmacological management of AIP in all age groups, hence there is a lower level of evidence base to recommend treatment options. The most judicious approach is prevention of AIP, considering the pros and cons of initiating APs, especially in those in higher risk groups. If an AP is to be commenced, a SGA at low dose should be used, and high-potency FGAs should be avoided. If AIP occurs, the first step should be a dose reduction, followed by discontinuation or switching to an alternative AP if possible. For the specific treatment of AIP in older adults, there is little evidence for effective pharmacological interventions. More research is required into the pathophysiological mechanisms underpinning AIP beyond the blockade of D2Rs, such as gene expression changes, which should lead to personalised prescribing, and into the pharmacological management of AIP using an RCT methodology. Clinicians should also consider more closely the patient and drug-related risks when prescribing APs. 
Author Contributions: Conceptualization: J.S.-M. Methodology: J.S.-M. and M.I. Validation: J.S.M., A.S., P.W., S.W., M.I. Formal Analysis: J.S.-M., A.S., P.W., S.W. Data Curation: J.S.-M. and M.I. Writing-Original Draft Preparation: J.S.-M., A.S., P.W., S.W., M.I. Writing—Review \& Editing: J.S.-M., A.S., P.W., S.W., M.I. All authors have read and agreed to the published version of the manuscript.

Funding: No funding was received by any of the authors to undertake this work.

Institutional Review Board Statement: Not applicable.

Informed Consent Statement: Not applicable.

Data Availability Statement: Not applicable.

Conflicts of Interest: The authors report no conflict of interest.

\section{References}

1. Marsden, C.D.; Jenner, P. The pathophysiology of extrapyramidal side-effects of neuroleptic drugs. Psychol. Med. 1980, 10, 55-72. [CrossRef] [PubMed]

2. Chou, K.L.; Friedman, J.H. Drug-induced parkinsonism in the elderly. Future Neurol. 2007, 2, 307-316. [CrossRef]

3. Druschky, K.; Bleich, S.; Grohmann, R.; Engel, R.; Toto, S.; Neyazi, A.; Däubl, B.; Stübner, S. Severe parkinsonism under treatment with antipsychotic drugs. Eur. Arch. Psychiatry Clin. Neurosci. 2019, 270, 35-47. [CrossRef] [PubMed]

4. Kim, J.S.; Youn, J.; Shin, H.; Cho, J.W. Nonmotor symptoms in drug-induced parkinsonism and drug-naive Parkinson disease. Can. J. Neurol. Sci. 2013, 40, 36-41. [CrossRef]

5. Caligiuri, M.P.; Lacro, J.P.; Jeste, D.V. Incidence and Predictors of Drug-Induced Parkinsonism in Older Psychiatric Patients Treated With Very Low Doses of Neuroleptics. J. Clin. Psychopharmacol. 1999, 19, 322-328. [CrossRef] [PubMed]

6. Morley, J.F.; Pawlowski, S.M.; Kesari, A.; Maina, I.; Pantelyat, A.; Duda, J.E. Motor and non-motor features of Parkinson's disease that predict persistent drug-induced Parkinsonism. Park. Relat. Disord. 2014, 20, 738-742. [CrossRef] [PubMed]

7. Lopez-Sendon, J.L.; Mena, M.A.; de Yebenes, J.G. Drug-Induced Parkinsonism in the Elderly; Incidence, Management and Prevention. Drugs Aging 2012, 29, 105-118. [CrossRef]

8. Estevez-Fraga, C.; Zeun, P.; Moreno, J.L.L.-S. Current Methods for the Treatment and Prevention of Drug-Induced Parkinsonism and Tardive Dyskinesia in the Elderly. Drugs Aging 2018, 35, 959-971. [CrossRef]

9. Savica, R.; Grossardt, B.; Bower, J.H.; Ahlskog, J.E.; Mielke, M.M.; Rocca, W.A. Incidence and time trends of drug-induced parkinsonism: A 30-year population-based study. Mov. Disord. 2017, 32, 227-234. [CrossRef] [PubMed]

10. Byun, J.-H.; Cho, H.; Kim, Y.J.; Kim, J.-S.; Baik, J.S.; Jang, S.; Ma, H.-I. Trends in the Prevalence of Drug-Induced Parkinsonism in Korea. Yonsei Med. J. 2019, 60, 760-767. [CrossRef]

11. Hoffman, W.F.; Sharon, M.L.; Daniel, E.C. Neuroleptic-Induced Parkinsonism in Older Schizophrenics. Biol. Psychiatry 1987, 22, 427-439. [CrossRef]

12. Rajput, A.H.; Offord, K.P.; Beard, C.M.; Kurland, L.T. Epidemiology of parkinsonism: Incidence, classification, and mortality. Ann. Neurol. 1984, 16, 278-282. [CrossRef] [PubMed]

13. Morgante, L.; Rosa, A.E.; Savettieri, G.; Reggio, A.; Patti, F.; Salemi, G.; Lorenzo, G.; Epifanio, A.; Perri, R. Drug-induced parkinsonism: Prevalence, clinical features and follow-up study in three Sicilian communities. J. Neurol. 1996, $243,293-301$. [CrossRef] [PubMed]

14. Bower, J.H.; Maraganore, D.M.; McDonnell, S.K.; Rocca, W.A. Incidence and distribution of parkinsonism in Olmsted County, Minnesota, 1976-1990. Neurology 1999, 52, 1214-1220. [CrossRef]

15. Baldereschi, M.; Di Carlo, A.; Rocca, W.A.; Vanni, P.; Maggi, S.; Perissinotto, E.; Grigoletto, F.; Amaducci, L.; Inzitari, D. Parkinson's disease and parkinsonism in a longitudinal study. Neurology 2000, 55, 1358-1363. [CrossRef]

16. Rocca, W.; Bower, J.; McDonnell, S.; Peterson, B.; Maraganore, D. Time trends in the incidence of parkinsonism in Olmsted County, Minnesota. Neurology 2001, 57, 462-467. [CrossRef] [PubMed]

17. Benito-León, J.; Bermejo-Pareja, F.; Morales-González, J.M.; Porta-Etessam, J.; Trincado, M.; Vega, S.; Louis, E.D. Incidence of Parkinson disease and parkinsonism in three elderly populations of central Spain. Neurology 2004, 62, 734-741. [CrossRef] [PubMed]

18. De Lau, L.; Giesbergen, P.; De Rijk, M.; Hofman, A.; Koudstaal, P.; Breteler, M. Incidence of parkinsonism and Parkinson disease in a general population: The Rotterdam Study. Neurology 2004, 63, 1240-1244. [CrossRef]

19. Barbosa, M.T.; Caramelli, P.; Maia, D.P.; Cunningham, M.C.; Guerra, H.L.; Lima-Costa, M.F.; Cardoso, F. Parkinsonism and Parkinson's disease in the elderly: A community-based survey in Brazil (the Bambui study). Mov. Disord. 2006, 21, 800-808. [CrossRef]

20. Munhoz, R.P.; Werneck, L.C.; Teive, H.A. The differential diagnoses of parkinsonism: Findings from a cohort of 1528 patients and a 10 years comparison in tertiary movement disorders clinics. Clin. Neurol. Neurosurg. 2010, 112, 431-435. [CrossRef]

21. Seijo-Martinez, M.; del Rio, M.C.; Alvarez, J.R.; Prado, R.S.; Salgado, E.T.; Esquete, J.P.; Sobrido, M.J. Prevalence of parkinsonism and Parkinson's disease in the Arosa Island (Spain): A community-based door-to-door survey. J. Neurol. Sci. 2011, 304, 49-54. [CrossRef] [PubMed] 
22. Savica, R.; Grossardt, B.; Bower, J.H.; Ahlskog, J.E.; Rocca, W.A. Incidence and Pathology of Synucleinopathies and Tauopathies Related to Parkinsonism. JAMA Neurol. 2013, 70, 859-866. [CrossRef] [PubMed]

23. Savica, R.; Grossardt, B.; Bower, J.H.; Ahlskog, J.E.; Rocca, W.A. Time Trends in the Incidence of Parkinson Disease. JAMA Neurol. 2016, 73, 981-989. [CrossRef] [PubMed]

24. Vale, T.C.; Barbosa, M.T.; Resende, E.D.P.F.; Maia, D.P.; Cunningham, M.C.Q.; Guimarães, H.C.; Machado, J.C.B.; Teixeira, A.L.; Cardoso, F.; Caramelli, P. Parkinsonism in a population-based study of individuals aged 75+ years: The Pietà study. Park. Relat. Disord. 2018, 56, 76-81. [CrossRef]

25. Fleury, V.; Brindel, P.; Nicastro, N.; Burkhard, P.R. Descriptive epidemiology of parkinsonism in the Canton of Geneva, Switzerland. Park. Relat. Disord. 2018, 54, 30-39. [CrossRef] [PubMed]

26. Bondon-Guitton, E.; Perez-Lloret, S.; Bagheri, H.; Brefel, C.; Rascol, O.; Montastruc, J.-L. Drug-induced parkinsonism: A review of 17 years' experience in a regional pharmacovigilance center in France. Mov. Disord. 2011, 26, 2226-2231. [CrossRef]

27. De Germay, S.; Montastruc, F.; Carvajal, A.; Lapeyre-Mestre, M.; Montastruc, J.L. Drug-induced parkinsonism: Revisiting the epidemiology using the WHO pharmacovigilance database. Park. Relat. Disord. 2020, 70, 55-59. [CrossRef] [PubMed]

28. Han, S.; Kim, S.; Kim, H.; Shin, H.W.; Na, K.S.; Suh, H.S. Prevalence and incidence of Parkinson's disease and drug-induced parkinsonism in Korea. BMC Public Health 2019, 19, 1328. [CrossRef]

29. Khedr, E.M.; Fawi, G.; Abbas MA, A.; Mohammed, T.A.; El-Fetoh, N.A.; Attar, G.A.; Zaki, A.F. Prevalence of Parkinsonism and Parkinson's disease in Qena governorate/Egypt: A cross-sectional community-based survey. Neurol. Res. 2015, 37, 607-618. [CrossRef]

30. Benito-León, J.; Bermejo-Pareja, F.; Rodríguez, J.; Molina, J.-A.; Gabriel, R.; Morales, J.-M.; For the Neurological Disorders in Central Spain (NEDICES) Study Group. Prevalence of PD and other types of parkinsonism in three elderly populations of central Spain. Mov. Disord. 2002, 18, 267-274. [CrossRef] [PubMed]

31. Wei, C.-Y.; Tzeng, I.-S.; Lin, M.-C.; Yeh, Y.-H.; Hsu, C.Y.; Kung, W.-M. Risks of Sulpiride-Induced Parkinsonism in Peptic Ulcer and Gastroesophageal Reflux Disease Patients in Taiwan: A Nationwide Population-Based Study. Front. Pharmacol. 2020, 11, 433. [CrossRef] [PubMed]

32. Caligiuri, M.P.; Rockwell, E.; Jeste, D.V. Extrapyramidal Side Effects in Patients with Alzheimer's Disease Treated with Low-Dose Neuroleptic Medication. Am. J. Geriatr. Psychiatry 1998, 6, 75-82. [CrossRef] [PubMed]

33. Writers, A.M. Minimize exposure to antidopaminergic drugs whenever possible to reduce the risk of drug-induced parkinsonism and tardive dyskinesia. Drugs Ther. Perspect. 2019, 35, 326-331. [CrossRef]

34. Friedman, J.H.; Fernandez, H.H.; Trieschmann, M.M. Parkinsonism in a Nursing Home: Underrecognition. J. Geriatr. Psychiatry Neurol. 2004, 17, 39-41. [CrossRef]

35. Tse, W.; Libow, L.S.; Neufeld, R.; Lesser, G.; Frank, J.; Dolan, S.; Tarshish, C.; Gracies, J.-M.; Olanow, C.W.; Koller, W.C.; et al. Prevalence of movement disorders in an elderly nursing home population. Arch. Gerontol. Geriatr. 2008, 46, 359-366. [CrossRef]

36. Moghal, S.; Rajput, A.; Meleth, R.; D’Arcy, C.; Rajput, R. Prevalence of Movement Disorders in Institutionalized Elderly. Neuroepidemiology 1995, 14, 297-300. [CrossRef] [PubMed]

37. Rochon, P.A.; Stukel, T.A.; Sykora, K.; Gill, S.S.; Garfinkel, S.; Anderson, G.M.; Normand, S.-L.T.; Mamdani, M.M.; Lee, P.E.; Li, P.; et al. Atypical Antipsychotics and Parkinsonism. Arch. Intern. Med. 2005, 165, 1882-1888. [CrossRef]

38. Munhoz, R.P.; Filho, D.B.; Teive, H.A.G. Not all drug-induced parkinsonism are the same: The effect of drug class on motor phenotype. Neurol. Sci. 2017, 38, 319-324. [CrossRef]

39. Shiraiwa, N.; Tamaoka, A.; Ohkoshi, N. Clinical Features of Drug-induced Parkinsonism. Neurol. Int. 2018, 10, 103-106. [CrossRef]

40. Oh, Y.-S.; Kwon, Y.; Kim, J.-S.; Park, M.-H.; Berg, D. Transcranial sonographic findings may predict prognosis of gastroprokinetic drug-induced parkinsonism. Park. Relat. Disord. 2018, 46, 36-40. [CrossRef]

41. Kim, S.; Cheon, S.-M.; Suh, H.S. Association Between Drug Exposure and Occurrence of Parkinsonism in Korea: A PopulationBased Case-Control Study. Ann. Pharmacother. 2019, 53, 1102-1110. [CrossRef] [PubMed]

42. Saltz, B.L.; Woerner, M.G.; Kane, J.M.; Lieberman, J.A.; Alvir, J.M.; Bergmann, K.J.; Blank, K.; Koblenzer, J.; Kahaner, K. Prospective study of tardive dyskinesia incidence in the elderly. JAMA Neurol. 1991, 266, 2402-2406.

43. McManus, D.Q.; Arvanitis, L.A.; Kowalcyk, B.B. Quetiapine, a novel antipsychotic: Experience in elderly patients with psychotic disorders. J. Clin. Psychiatry 1999, 60, 292-298. [CrossRef] [PubMed]

44. Tollefson, G.; Beasley, J.C.; Tamura, R. Blind, controlled, long-term study of the comparative incidence of treatment-emergent tardive dyskinesia with olanzapine or haloperidol. Am. J. Psychiatry 1997, 154, 1248-1254. [PubMed]

45. Katz, I.R.; Jeste, D.V.; Mintzer, J.E.; Clyde, C.; Napolitano, J.; Brecher, M. Comparison of risperidone and placebo for psychosis and behavioral disturbances associated with dementia: A randomized, double-blind trial. J. Clin. Psychiatry 1999, 60, 107-115. [CrossRef]

46. Llau, M.; Nguyen, L.; Senard, J.; Rascol, O.; Montastruc, J. Syndromes parkinsoniens d'origine médicamenteuse: Expérience d'un centre régional de pharmacovigilance sur dix ans [Drug-induced parkinsonian syndromes: A 10-year experience at a regional center of pharmaco-vigilance]. Rev. Neurol. 1994, 150, 757-762. [PubMed]

47. Thanvi, B.; Treadwell, S. Drug induced parkinsonism: A common cause of parkinsonism in older people. Postgrad. Med. J. 2009, 85, 322-326. [CrossRef]

48. Lera, G.; Zirulnik, J. Pilot study with clozapine in patients with HIV-associated psychosis and drug-induced parkinsonism. Mov. Disord. 1999, 14, 128-131. [CrossRef] 
49. Hriso, E.; Kuhn, T.; Masdeu, J.C.; Grundman, M. Extrapyramidal symptoms due to dopamine-blocking agents in patients with AIDS encephalopathy. Am. J. Psychiatry 1991, 148, 1558-1561. [CrossRef]

50. Foubert-Samier, A.; Helmer, C.; Pérez, F.; Le Goff, M.; Auriacombe, S.; Elbaz, A.; Dartigues, J.-F.; Tison, F. Past exposure to neuroleptic drugs and risk of Parkinson disease in an elderly cohort. Neurology 2012, 79, 1615-1621. [CrossRef]

51. Galoppin, M.; Berroir, P.; Soucy, J.-P.; Suzuki, Y.; Lavigne, G.J.; Gagnon, J.-F.; Montplaisir, J.Y.; Stip, E.; Blanchet, P.J. Chronic Neuroleptic-Induced Parkinsonism Examined with Positron Emission Tomography. Mov. Disord. 2020, 35, 1189-1198. [CrossRef] [PubMed]

52. Chabolla, D.R.; Maraganore, D.M.; Ahlskog, J.E.; O’Brien, P.C.; Rocca, W.A. Drug-induced parkinsonism as a risk factor for Parkinson's disease: A Historical Cohort Study in Olmsted County, Minnesota. Mayo Clin. Proc. 1998, 73, 724-727. [CrossRef] [PubMed]

53. Fernandez, H.; Factor, S.; Hauser, R.; Jimenez-Shahed, J.; Ondo, W.; Jarskog, L.; Meltzer, H.; Woods, S.; Bega, D.; LeDoux, M.; et al. Randomized controlled trial of deutetrabenazine for tardive dyskinesia: The ARM-TD study. Neurology 2017, 88, 2003-2010. [CrossRef] [PubMed]

54. Kapur, S.; Seeman, P. Does fast dissociation from the dopamine D2 receptor explain the action of atypical antipsychotics? A new hypothesis. Am. J. Psychiatry 2001, 158, 360-369. [CrossRef] [PubMed]

55. Trosch, R.M. Neuroleptic-Induced Movement Disorders: Deconstructing Extrapyramidal Symptoms. Am. Geriatr. Soc. 2004, 52, S266-S271. [CrossRef]

56. Seeman, P. Clozapine, a Fast-Off-D2 Antipsychotic. ACS Chem. Neurosci. 2014, 5, 24-29. [CrossRef]

57. Remington, G.; Seeman, P.; Feingold, A.; Mann, S.; Shammi, C.; Kapur, S. "Extended" antipsychotic dosing in the maintenance treatment of schizophrenia: A double-blind, placebocontrolled trial. J. Clin. Psychiatry 2011, 72, 1042-1048. [CrossRef]

58. Tarsy, D.; Baldessarini, R.J.; Tarazi, F.I. Effects of Newer Antipsychotics on Extrapyramidal Function. CNS Drugs 2002, 16, 23-45. [CrossRef]

59. Mas, S.; Gasso, P.; Parellada, E.; Bernardo, M.; Lafuente, A. Network analysis of gene expression in peripheral blood identifies mTOR and NF-kappaB pathways involved in antipsychotic-induced extrapyramidal symptoms. Pharm. J. 2015, 15, 452-460.

60. Mas, S.; Gassó, P.; Lafuente, A. Applicability of gene expression and systems biology to develop pharmacogenetic predictors; antipsychotic-induced extrapyramidal symptoms as an example. Pharm. J. 2015, 16, 1975-1988. [CrossRef]

61. Boloc, D.; Gortat, A.; Cheng-Zhang, J.Q.; Garcia-Cerro, S.; Rodriguez, N.; Parellada, M.; Saiz-Ruiz, J.; Cuesta, M.J.; Gassó, P.; Lafuente, A.; et al. Improving pharmacogenetic prediction of extrapyramidal symptoms induced by antipsychotics. Transl. Psychiatry 2018, 8, 276. [CrossRef] [PubMed]

62. Boloc, D.; Rodríguez, N.; Torres, T.; García-Cerro, S.; Parellada, M.; Saiz-Ruiz, J.; Cuesta, M.J.; Bernardo, M.; Gassó, P.; Lafuente, A.; et al. Identifying key transcription factors for pharmacogenetic studies of antipsychotics induced extrapyramidal symptoms. Psychopharmacology 2020, 237, 2151-2159. [CrossRef] [PubMed]

63. Erro, R.; Bhatia, K.P.; Tinazzi, M. Parkinsonism following neuroleptic exposure: A double-hit hypothesis? Mov. Disord. 2015, 30, 780-785. [CrossRef] [PubMed]

64. Chung, S.J.; Yoo, H.S.; Moon, H.; Oh, J.S.; Kim, J.S.; Park, Y.H.; Hong, J.Y.; Ye, B.S.; Sohn, Y.H.; Lee, P.H. Early-onset drug-induced parkinsonism after exposure to offenders implies nigrostriatal dopaminergic dysfunction. J. Neurol. Neurosurg. Psychiatry 2018, 89, 169-174. [CrossRef]

65. Lee, Y.; Choi, Y.H.; Lee, J.J.; Lee, H.S.; Sohn, Y.H.; Lee, J.-M.; Lee, P.H. Microstructural white matter alterations in patients with drug induced parkinsonism. Hum. Brain Mapp. 2017, 38, 6043-6052. [CrossRef] [PubMed]

66. Yoo, H.S.; Bak, Y.; Chung, S.J.; Lee, Y.; Ye, B.S.; Sohn, Y.H.; Shin, N.-Y.; Lee, P.H. Impaired functional connectivity of sensorimotor network predicts recovery in drug-induced parkinsonism. Park. Relat. Disord. 2020, 74, 16-21. [CrossRef]

67. Hughes, A.J.; Daniel, S.E.; Kilford, L.; Lees, A.J. Accuracy of clinical diagnosis of idiopathic Parkinson's disease: A clinicopathological study of 100 cases. J. Neurol. Neurosurg. Psychiatry 1992, 55, 181-184. [CrossRef]

68. American Psychiatric Association. Diagnostic and Statistical Manual of Mental Disorders, 5th ed.; American Psychiatric Association: Washington, DC, USA, 2013.

69. Blanchet, P.J.; Kivenko, V. Drug-induced parkinsonism: Diagnosis and management. J. Park. Restless Legs Syndr. 2016, 6, 83-91. [CrossRef]

70. Simpson, G.M.; Angus, J.W.S. A Rating Scale for Extrapyramidal Side Effects. Acta Psychiatr. Scand. Suppl. 1970, $212,11-19$. [CrossRef]

71. Knol, W.; Keijsers, C.J.P.W.; Jansen, P.A.F.; Belitser, S.V.; Schobben, A.F.A.M.; Egberts, A.C.G.; Van Marum, R.J. Validity and reliability of the Simpson-Angus Scale (SAS) in drug induced parkinsonism in the elderly. Int. J. Geriatr. Psychiatry 2009, 24, 183-189. [CrossRef]

72. Hardie, R.J.; Lees, A.J. Neuroleptic-induced Parkinson's syndrome: Clinical features and results of treatment with levodopa. J. Neurol. Neurosurg. Psychiatry 1988, 51, 850-854. [CrossRef] [PubMed]

73. Lorberboym, M.; Treves, T.; Melamed, E.; Lampl, Y.; Hellmann, M.; Djaldetti, R. [123I]-FP/CIT SPECT imaging for distinguishing drug-induced parkinsonism from Parkinson's disease. Mov. Disord. 2006, 21, 510-514. [CrossRef]

74. Mena, M.; de Yébenes, J. Drug-induced parkinsonism. Expert Opin. Drug Saf. 2006, 5, 759-771. [CrossRef] [PubMed] 
75. Diaz-Corrales, F.J.; Sanz-Viedma, S.; Garcia-Solis, D.; Escobar-Delgado, T.; Mir, P. Clinical features and 123I-FP-CIT SPECT imaging in drug-induced parkinsonism and Parkinson's disease. Eur. J. Nucl. Med. Mol. Imaging 2010, 37, 556-564. [CrossRef] [PubMed]

76. Hassin-Baer, S.; Sirota, P.; Korczyn, A.D.; Treves, T.A.; Epstein, B.; Shabtai, H.; Martin, T.; Litvinjuk, Y.; Giladi, N. Clinical characteristics of neuroleptic-induced parkinsonism. J. Neural Transm. 2001, 108, 1299-1308. [CrossRef] [PubMed]

77. Shin, H.-W.; Kim, J.S.; Oh, M.; You, S.; Kim, Y.J.; Kim, J.; Kim, M.-J.; Chung, S.J. Clinical features of drug-induced parkinsonism based on [18F] FP-CIT positron emission tomography. Neurol. Sci. 2015, 36, 269-274. [CrossRef]

78. Sethi, K.D.; Zamrini, E.Y. Asymmetry in clinical features of drug-induced parkinsonism. J. Neuropsychiatry Clin. Neurosci. 1990, 2, 64-66. [CrossRef]

79. Tinazzi, M.; Antonini, A.; Bovi, T.; Pasquin, I.; Steinmayr, M.; Moretto, G.; Fiaschi, A.; Ottaviani, S. Clinical and [123I]FP-CIT SPET imaging follow-up in patients with drug-induced parkinsonism. J. Neurol. 2009, 256, 910-915. [CrossRef]

80. Ovallath, S.; Sulthana, B. Drug Induced Parkinsonism: An Overview. Open Access J. Neurol. Neurosurg. 2017, 3, 56-60. [CrossRef]

81. Bruce, L.S.; Margaret, G.W.; Delbert, G.R.; John, M.K. Side effects of Antipsychotic Drugs; Avoiding and minimizing their impact in elderly patients. Postgrad. Med. 2000, 107, 169-178.

82. Powell, A.; Gallur, L.; Koopowitz, L.; Hayes, M.W. Parkinsonism in the psychiatric setting: An update on clinical differentiation and management. BMJ Neurol. Open 2020, 2, e000034. [CrossRef] [PubMed]

83. Krüger, S.; Haehner, A.; Thiem, C.; Hummel, T. Neuroleptic-induced parkinsonism is associated with olfactory dysfunction. J. Neurol. 2008, 255, 1574-1579. [CrossRef] [PubMed]

84. Lee, P.H.; Yeo, S.H.; Yong, S.W.; Kim, Y.J. Odour identification test and its relation to cardiac 123I-metaiodobenzylguanidine in patients with drug induced parkinsonism. J. Neurol. Neurosurg. Psychiatry 2007, 78, 1250-1252. [CrossRef] [PubMed]

85. Bovi, T.; Antonini, A.; Ottaviani, S.; Antonioli, A.; Cecchini, M.P.; Di Francesco, V.; Bassetto, M.; Zamboni, M.; Fiaschi, A.; Moretto, G.; et al. The status of olfactory function and the striatal dopaminergic system in drug-induced parkinsonism. J. Neurol. 2010, 257, 1882-1889. [CrossRef] [PubMed]

86. Roussakis, A.; Piccini, P.; Politis, M. Clinical utility of DaTscan ${ }^{\mathrm{TM}}$ (123I-Ioflupane Injection) in the diagnosis of Parkinsonian Syndromes. Degener. Neurol. Neuromuscul. Dis. 2013, 3, 33-39. [CrossRef]

87. Brigo, F.; Matinella, A.; Erro, R.; Tinazzi, M. [(1)(2)(3)I]FP-CIT SPECT (DaTSCAN) may be a useful tool to differentiate between Parkinson's disease and vascular or drug-induced parkinsonisms: A meta-analysis. Eur. J. Neurol. 2014, 21, 1369-e90. [CrossRef]

88. Factor, S.A.; Burkhard, P.R.; Caroff, S.; Friedman, J.H.; Marras, C.; Tinazzi, M.; Comella, C.L. Recent developments in drug-induced movement disorders: A mixed picture. Lancet Neurol. 2019, 18, 880-890. [CrossRef]

89. Kägi, G.; Klein, C.; Wood, N.W.; Schneider, S.A.; Pramstaller, P.P.; Tadić, V.; Quinn, N.P.; Van De Warrenburg, B.P.; Bhatia, K.P. Nonmotor symptoms in Parkin gene-related parkinsonism. Mov. Disord. 2010, 25, 1279-1284. [CrossRef]

90. Tinazzi, M.; Cipriani, A.; Matinella, A.; Cannas, A.; Solla, P.; Nicoletti, A.; Zappia, M.; Morgante, L.; Morgante, F.; Pacchetti, C.; et al. [(1)(2)(3)I]FP-CIT single photon emission computed tomography findings in drug-induced Parkinsonism. Schizophr. Res. 2012, 139, 40-45. [CrossRef]

91. Olivares Romero, J.; Arjona Padillo, A. Diagnostic accuracy of 123 I-FP-CIT SPECT in diagnosing drug-induced parkinsonism: A prospective study. Neurologia 2013, 28, 276-282. [CrossRef]

92. Jin, S.; Oh, M.; Oh, S.J.; Oh, J.S.; Lee, S.J.; Chung, S.J.; Lee, C.S.; Kim, J.S. Differential Diagnosis of Parkinsonism Using Dual-Phase F-18 FP-CIT PET Imaging. Nucl. Med. Mol. Imaging 2013, 47, 44-51. [CrossRef]

93. Park, E.; Hwang, Y.M.; Lee, C.-N.; Kim, S.; Oh, S.Y.; Kim, Y.C.; Choe, J.G.; Park, K.W. Differential Diagnosis of Patients with Inconclusive Parkinsonian Features Using [(18)F]FP-CIT PET/CT. Nucl. Med. Mol. Imaging 2014, 48, 106-113. [CrossRef]

94. Sadasivan, S.; Friedman, J.H. Experience with DaTscan at a tertiary referral center. Park. Relat. Disord. 2015, 21, 42-45. [CrossRef] [PubMed]

95. Bega, D.; Gonzalez-Latapi, P.; Zadikoff, C.; Spies, W.; Simuni, T. Is There a Role for DAT-SPECT Imaging in a Specialty Movement Disorders Practice? Neurodegener. Dis. 2015, 15, 81-86. [CrossRef]

96. Hong, J.Y.; Sunwoo, M.K.; Oh, J.S.; Kim, J.S.; Sohn, Y.H.; Lee, P.H. Persistent Drug-Induced Parkinsonism in Patients with Normal Dopamine Transporter Imaging. PLoS ONE 2016, 11, e0157410. [CrossRef] [PubMed]

97. Bhattacharjee, S.; Chalissery, A.; Barry, T.; O'Sullivan, D.; O'Connell, M.; Lynch, T. Referral practice, reporting standards, and the impact of dopamine transporter scans done in a tertiary hospital. Neurol. India 2017, 65, 1264. [CrossRef]

98. Shin, H.-W.; Chung, S.J. Drug-Induced Parkinsonism. J. Clin. Neurol. 2012, 8, 15-21. [CrossRef]

99. Rascol, O.; Schelosky, L. 123I-metaiodobenzylguanidine scintigraphy in Parkinson's disease and related disorders. Mov. Disord. 2009, 24, S732-S741. [CrossRef]

100. Lee, P.H.; Kim, J.S.; Shin, D.H.; Yoon, S.-N.; Huh, K. Cardiac 123I-MIBG scintigraphy in patients with drug induced parkinsonism. J. Neurol. Neurosurg. Psychiatry 2006, 77, 372-374. [CrossRef]

101. Chaudhuri, K.; Healy, D.; Schapira, A. National Institute for Clinical Excellence. Non-motor symptoms of Parkinson's disease: Diagnosis and management. Lancet Neurol. 2006, 5, 235-245. [CrossRef]

102. Vlaar, A.M.; De Nijs, T.; Kessels, A.G.; Vreeling, F.W.; Winogrodzka, A.; Mess, W.H.; Tromp, S.C.; Van Kroonenburgh, M.J.; Weber, W.E. Diagnostic Value of 123I-Ioflupane and 123I-Iodobenzamide SPECT Scans in 248 Patients with Parkinsonian Syndromes. Eur. Neurol. 2008, 59, 258-266. [CrossRef] [PubMed] 
103. López-Sendón Moreno, J.; Alonso-Cánovas, A.; Buisán Catevilla, J. Substantia nigra echogenicity predicts response to drug withdrawal in suspected drug-induced parkinsonism. Mov. Disord. Clin. Pract. 2016, 3, 268-274. [CrossRef]

104. Mahlknecht, P.; Stockner, H.; Kiechl, S.; Willeit, J.; Rastner, V.; Gasperi, A.; Rungger, G.; Poewe, W.; Seppi, K. Is transcranial sonography useful to distinguish drug-induced parkinsonism from Parkinson's disease? Mov. Disord. 2012, 27, 1194-1196. [CrossRef] [PubMed]

105. Sung, Y.H.; Noh, Y.; Lee, J.; Kim, E.Y. Drug-induced Parkinsonism versus Idiopathic Parkinson Disease: Utility of Nigrosome 1 with 3-T Imaging. Radiology 2016, 279, 849-858. [CrossRef] [PubMed]

106. Gamboa, J.; Jiménez-Jiménez, F.; Nieto, A.; Montojo, J.; Ortí-Pareja, M.; Molina, J.; Cobeta, I. Acoustic voice analysis in patients with Parkinson's disease treated with dopaminergic drugs. J. Voice 1997, 11, 314-320. [CrossRef]

107. Mamo, D.C.; Sweet, R.A.; Keshavan, M.S. Managing Antipsychotic-Induced Parkinsonism. Drug Saf. 1999, 20, 269-275. [CrossRef] [PubMed]

108. Howard, R.; Cort, E.; Bradley, R.; Harper, E.; Kelly, L.; Bentham, P.; Ritchie, C.; Reeves, S.; Fawzi, W.; Livingston, G.; et al. Antipsychotic treatment of very late-onset schizophrenia-like psychosis (ATLAS): A randomised, controlled, double-blind trial. Lancet Psychiatry 2018, 5, 553-563. [CrossRef]

109. Reeves, S.; Bertrand, J.; Uchida, H.; Yoshida, K.; Otani, Y.; Ozer, M.; Howard, R. Towards safer risperidone prescribing in Alzheimer's disease. Br. J. Psychiatry 2020, 218, 268-275. [CrossRef]

110. Kalish, S.C.; Bohn, R.L.; Mogun, H.; Glynn, R.J.; Gurwitz, J.H.; Avorn, J. Antipsychotic Prescribing Patterns and the Treatment of Extrapyramidal Symptoms in Older People. J. Am. Geriatr. Soc. 1995, 43, 967-973. [CrossRef]

111. Margolesky, J.; Betté, S.; Singer, C. Management of Urologic and Sexual Dysfunction in Parkinson Disease. Clin. Geriatr. Med. 2020, 36, 69-80. [CrossRef]

112. Keks, N.; Schwartz, D.; Hope, J. Stopping and switching antipsychotic drugs. Aust. Prescr. 2019, 42, 152-157. [CrossRef]

113. Parkinson Study Group. Low-dose clozapine for the treatment of drug-induced psychosis in Parkinson's disease. N. Engl. J. Med. 1999, 340, 757-763. [CrossRef]

114. Kirrane, A.; Majumdar, B.; Richman, A. Clozapine use in old age psychiatry. BJPsych Adv. 2018, 24, 204-211. [CrossRef]

115. Friedman, J. Viewpoint: Challenges in our understanding of neuroleptic induced parkinsonism. Parkinsonism Relat. Disord. 2014, 20, 1325-1328. [CrossRef] [PubMed]

116. Ward, K.M.; Citrome, L. Antipsychotic-Related Movement Disorders: Drug-Induced Parkinsonism vs. Tardive Dyskinesia-Key Differences in Pathophysiology and Clinical Management. Neurol. Ther. 2018, 7, 233-248. [CrossRef]

117. Aoki, F.Y.; Sitar, D.S. Clinical Pharmacokinetics of Amantadine Hydrochloride. Clin. Pharmacokinet. 1988, 14, 35-51. [CrossRef] [PubMed]

118. Fann, W.E.; Lake, C.R. Amantadine versus trihexyphenidyl in the treatment of neuroleptic- induced parkinsonism. Am. J. Psychiatry 1976, 133, 940-943. [CrossRef] [PubMed]

119. Mindham, R.H.S. Assessment of drug-induced extrapyramidal reactions and of drugs given for their control. Br. J. Clin. Pharmac. 1976, 3, 395-400. [CrossRef]

120. Wilson, J.A.; Maclennan, W.J. Review: Drug-induced Parkinsonism in Elderly Patients. Age Ageing 1989, 18, 208-210. [CrossRef]

121. Moellentine, C.; Rummans, T.; Ahlskog, J.E.; Harmsen, W.S.; Suman, V.J.; O'Connor, M.K.; Black, J.L.; Pileggi, T. Effectiveness of ECT in Patients with Parkinsonism. J. Neuropsychiatry Clin. Neurosci. 1998, 10, 187-193. [CrossRef]

122. Baez, M.A.; Avery, J. Improvement in Drug-Induced Parkinsonism with Electroconvulsive Therapy. Am. J. Geriatr. Pharmacother. 2011, 9, 190-193. [CrossRef] [PubMed]

123. Sadananda, S.K.; Holla, B.; Viswanath, B.; Narasimha, A.; Sebastian, A.; Math, S.B.; Chandrashekar, C.R. Effectiveness of Electroconvulsive Therapy for Drug-Induced Parkinsonism in the Elderly. J. ECT 2013, 29, e6-e7. [CrossRef] [PubMed] 